\title{
Export emergence of differentiated goods from developing countries: Export pioneers and business practices in Argentina ${ }^{2}$
}

\author{
Alejandro Artopoulos ${ }^{\mathrm{a}, \mathrm{b}, 1}$, Daniel Friel ${ }^{\mathrm{a}, 2}$, Juan Carlos Hallak ${ }^{\mathrm{a}, \mathrm{c}, \mathrm{d}, *}$ \\ a Universidad de San Andrés, Vito Dumas 284, Victoria, Buenos Aires, Argentina \\ b CIC, Argentina \\ c NBER, United States \\ d CONICET, Argentina
}

\section{A R T I C L E I N F O}

\section{Article history:}

Received 7 July 2011

Received in revised form 20 June 2013

Accepted 8 July 2013

Available online 16 July 2013

\section{JEL classification:}

F10

F14

M13

M16

014

033

\section{Keywords:}

Export business practices

Export emergence

Embeddedness

Export pioneer

Diffusion

Case studies

Product quality

Export dynamics

\begin{abstract}
A B S T R A C T
This study explores the underlying factors that enable firms from developing countries to successfully export differentiated goods to developed countries. The article describes four case studies of export emergence in differentiated-good sectors in Argentina, namely wine, television programs, motorboats, and wooden furniture. The case studies rely primarily on an extensive set of interviews. We find that consistent exporters to developed countries adopt a new set of business practices that differ starkly from those that prevail in their domestic market. In three of the sectors, an export pioneer led the adoption of these new practices. Export pioneers possessed tacit knowledge about foreign markets, achieved through their previous embeddedness in the business community of those markets. Export emergence occurs as business practices diffuse throughout the sector. These findings point to the importance of foreign market knowledge, relative to production knowledge, as the key constraint to achieve consistent export to developed countries.
\end{abstract}

(c) 2013 Elsevier B.V. All rights reserved.

\section{Introduction}

Numerous episodes of export emergence have been documented for specific industries in developing countries. This prevalent phenomenon

\footnotetext{
We thank Facundo Albornoz, Costas Arkolakis, Sebastián García Dastugue, Ernesto Gore, Ezequiel Groisman, Ricardo Hausmann, Diego Puga, Andrés Rodriguez-Clare, Christian Ruzzier, Peter Schott, Ernesto Stein, John Sutton, Dan Trefler, Jon Vogel, seminar participants at the IDB, Michigan, San Andrés, San Diego, Toronto, UNC, UTDT, Yale, and participants at various conferences for their helpful comments. We also greatly appreciate comments by the Editor Eric Verhoogen and two anonymous referees. The authors acknowledge the financial support of the Inter American Development Bank. Juan Carlos Hallak acknowledges support by the NSF (Grant No. SES 0550190). Alejandro Molnar, Santiago Pérez, Santiago Sautúa, and Gabriela Yu provided outstanding research assistance.

* Corresponding author at: Universidad de San Andrés, Vito Dumas 284, Victoria, Buenos Aires, Argentina. Tel.: +54114725 7081 .

E-mail addresses: alepoulos@udesa.edu.ar (A. Artopoulos),dfriel@udesa.edu.ar (D. Friel), jchallak@udesa.edu.ar (J.C. Hallak).

1 Tel.: +54114725 7057 .

2 Tel.: + 541147256945 .
}

consists in the sudden appearance of a large number of firms rapidly making headways into international markets (Hausmann and Rodrik, 2003; Rhee and Belot, 1990). Some of the best-known cases are the emergence of textile exports from Bangladesh (Rhee, 1990), cut-flowers from Colombia (Arbeláez et al., 2012; Rhee and Belot, 1990), and women's shoes from Brazil (Schmitz, 1995). The volume of foreign sales that results from these processes is often substantial and sometimes accounts for a large fraction of exports of developing countries. Since a hallmark of countries that have industrialized in the last fifty years (e.g. Japan, South Korea, and China) is the impressive growth of their exports, understanding instances of export emergence might be key to understanding broader determinants of export development and late industrialization.

Established international trade theories cannot explain why exports in specific sectors suddenly surge. While the Heckscher-Ohlin theory is unable to explain why exports emerge in some sectors but not in others that use similar factor intensities, the Ricardian theory is silent about the potential drivers of productivity change that could ignite this process. In turn, heterogeneous firm theories focused on the determinants and 
dynamics of foreign market entry do not explain why firms in the same sector enter export markets contemporaneously. An influential paper by Hausmann and Rodrik (2003) (HR) develops a theory of sectoral export emergence in which an export pioneer triggers a process of export emergence by discovering that the production costs of a new economic activity are low. As this theory only deals with homogeneous goods, it does not capture well-known hindrances to exporting differentiated products stemming from informational barriers (Rauch, 1999) and the need to pay fixed and sunk costs (Roberts and Tybout, 1997). As a result, it does not explain why and how export emergence in differentiated products takes place. In particular, this theory does not deal with the causes of the export emergence of such products to developed countries, where those hindrances are higher.

Our work attempts to describe and explain this process. We conduct case studies of export emergence to developed countries in four Argentine differentiated-good sectors: wines, television programs, motorboats, and wooden furniture. These sectors span a broad diversity of economic activities. In each of the cases, we interview relevant actors, observe production processes, and collect statistical data. Based on the data gathered through these various sources, we identify and describe the main common patterns across the cases and construct hypotheses to explain them.

One of our most salient findings is that consistent exporters to developed countries (henceforth consistent exporters) adopt a new set of business practices (henceforth export business practices). These practices are radically different from those that prevail in the domestic market. They involve adapting products to foreign demand and establishing information channels to keep up to date about its evolving patterns. These practices also require upgrading production processes to improve quality, complying with stringent requirements of foreign distributors, and seeking to establish long-term relationships with them to secure up-to-date information about foreign markets. Consistent exporters also exhibit a common mindset about the importance of adopting export business practices and a discourse that implicitly assumes their complementarity. This finding relates to a voluminous literature in international trade on the determinants of the exporting behavior of firms (Melitz and Redding, forthcoming) that has so far overlooked the need to change business practices to enter markets in developed countries (henceforth developed markets). Although some papers point to the importance of quality upgrading (e.g. Hallak and Sivadasan, forthcoming; Sutton, 2007; Verhoogen, 2008), we find here that entering developed markets requires that firms change a substantially broader set of business practices.

We also find in our fieldwork that in three of our four industries an export pioneer is the first to adopt this broad set of export business practices and the first to consistently export to a developed country. By contrast, in the wooden furniture industry we do not find an export pioneer. Strikingly, the three export pioneers exhibit a previous exposure to developed markets as a common feature in their background. This is unlikely to be coincidental since this background is rare among Argentine producers. Rather, it points to foreign market knowledge as a critical constraint to achieving consistent exports to the developed world. We argue that the embeddedness (Granovetter, 1985) of export pioneers in the business community of their industries in developed markets enabled them to acquire this tacit knowledge and eventually envision a viable way of establishing an export business based on the adoption of a new set of business practices. Export pioneers then trigger a process of export emergence in their industries by spurring the diffusion of those practices. They set an observable benchmark by demonstrating that exporting consistently to developed countries is possible and profitable. Their actions also convince others that exporting to developed markets requires business practices to be changed.

The fact that export pioneers exhibit a substantial foreign exposure as a common feature in their background questions the conventional focus on productivity as the main determinant of firm exports (Bernard et al., 2003; Melitz, 2003). This finding points to foreign market knowledge, not production knowledge, as the key for developing country firms to establish a stable presence in developed markets. The finding is consistent with recent case-study work showing that the possession of foreign market knowledge is a distinguishing feature of large African producers and exporters (Easterly and Reshef, 2010; Sutton and Kellow, 2010; Sutton and Kpentey, 2012) and with evidence that managers with previous experience at exporting firms increase the probability of exporting of their current employers (Mion and Opromolla, 2010; Molina and Muendler, 2013). It is also noteworthy that in none of our cases are multinationals the export pioneers or one of the earliest followers.

As in $\mathrm{HR}$, we also explain export emergence using a pioneerdiffusion framework. However, we point to different drivers of this process. Specifically, while export emergence in HR unravels as firms learn the production costs of a new economic activity, our case studies of differentiated-good sectors suggest that this process unravels as firms acquire foreign market knowledge and adopt export business practices. ${ }^{3}$ Hence, policies that spur discovery activity, as HR recommend, may not be effective unless firms gain a prior understanding of foreign markets and change their business practices to serve them. In related work, Sabel et al. (2012) emphasize the resolution of coordination problems as the main trigger of export emergence. ${ }^{4}$ While we also identify coordination problems in our case studies, we do not find that export emergence is triggered by the resolution of this type of problems. ${ }^{5}$ Freund and Pierola (2010), lacovone and Javorcik (2010), and Wagner and Zhaler (2013) develop statistical criteria to identify export pioneers from customs data. Export business practices, however, cannot be investigated following this approach since customs data are silent about firms' business practices.

The cases of export emergence we describe here represent an alternate means of international insertion relative to integration in global value chains (GVC). Integration into GVC under contract manufacturing arrangements that do not require performing design and marketing tasks has helped firms in developing countries to overcome a lack of foreign market knowledge (Gereffi, 1999; Abernathy et al. 1999). Keesing and Lall (1990) document the role of intermediaries and international buyers in initiating this type of integration. These agents approach domestic producers, provide them with designs, and gradually teach them how to change their products and business practices to conform to their demands. In our cases, the activity of this kind of agent is notoriously scarce, potentially because this type of initial insertion in GVC is more pervasive in countries where very low wages attract unskilled labor-intensive tasks in the production of standardized products. In contrast, exported products in our four sectors exhibit an important component of (domestically-performed) design. While gaining the ability to design goods that appeal to consumers in developed markets may be eventually achieved through upgrading within GVC (Gereffi, 1999), often this form of upgrading does not occur (Humphrey and Schmitz, 2002). Thus, the type of export insertion that our case studies represent might constitute a source of better, high paying jobs.

Although we cannot ascertain how export performance in the industries we study would have evolved in the absence of export pioneers, our findings suggest that sustained export growth would not have occurred or would have been substantially delayed in such cases. Also, they suggest that the absence of an export pioneer, as in the wooden furniture sector in our study, could be a potential explanation for why

\footnotetext{
${ }^{3}$ Klepper and Rommel's (2011) analysis of the emergence of Bangladesh's garment industry also emphasizes production knowledge as the object of diffusion.

4 Sabel et al. (2012) document a number of Latin American case studies conducted under a large project lead by the Inter-American Development Bank (IDB). Most of our field work was conducted in 2006 as part of this project.

${ }^{5}$ The discrepancy may stem from the predominance in the IDB project of industries with limited scope for product differentiation (e.g. cut flowers in Colombia, avocados in Mexico). In those industries, coordination among producers, or between producers and public agencies, would appear to be necessary to sustain activities that generate large externalities (e.g. experiments with new seeds) or that demand the provision of public goods (e.g. roads or air transport)
} 
a priori similarly promising sectors do not display sustained export activity. Thus, identifying the main constraints to exporting and understanding why the background of export pioneers loosens those constraints may contribute to the design of public policies to promote cross-sectoral diffusion and help firms deal with similar difficulties in sectors where an export pioneer does not appear spontaneously.

The rest of the paper proceeds as follows. In Section 2, we describe our methodology. In Section 3, we provide a brief description of each case study. ${ }^{6}$ In Section 4, we summarize and discuss the main common findings across the cases. In Section 5 , we provide concluding remarks.

\section{Methodology}

This paper describes four Argentine case studies of export emergence oriented to developed countries in differentiated-good sectors. Based on these studies, we develop a set of related hypotheses about the determinants of this phenomenon. Our case studies are based on a variety of data sources (Yin, 1994), although primarily they rely on the collection of qualitative data. In the presence of an understudied phenomenon, the richness of qualitative data can provide insights into complex processes that quantitative data cannot easily reveal (Eisenhardt and Graebner, 2007). In each of the cases, we interview a variety of relevant actors to obtain multiple perspectives (Helper, 2000) on how export emergence occurred and what enabled firms to consistently export to developed markets. We triangulated this information with information obtained from local trade associations, academic studies, industry reports, and customs data.

Our main criterion for choosing our four cases among differentiatedgood sectors exhibiting export emergence substantially oriented to developed countries was to span the diverse set of activities that make differentiated goods: agriculture-based manufacturing (wines), traditional industrial manufacturing (wooden furniture), non-traditional industrial manufacturing (motorboats), and services (television programs). ${ }^{7}$ We did not include highly concentrated sectors in our study (e.g. automobiles and electronics), which have high entry barriers and require large fixed outlays in R\&D or advertising, nor did we include intermediate goods. While export emergence in those sectors might have different determinants than the ones we emphasize here, our findings might still apply, albeit partially, to these types of sectors. To identify potential sectors, we used customs data to filter 4-digit Harmonized System (HS) categories that satisfied the following criteria: (a) $40 \%$ top percentile of export growth during the period 1991-2005; (b) at least $1 / 3$ of exports shipped to OECD countries; and (c) more than 10 million U.S. dollar exports in 2005. We obtained thirty sectors that satisfied these criteria. Thirteen of them are classified by Rauch (1999) as differentiated and the remaining seventeen as non-differentiated. ${ }^{8}$ The wine and wooden furniture industries were selected after conducting this statistical analysis. ${ }^{9}$ The motorboats and television program industries were identified based on one of the author's previous knowledge of the recent export emergence of these sectors in Argentina and selected after confirming that they also satisfied the above criteria. ${ }^{10}$ The case of wooden furniture proved later not to be a case of sustained export emergence to developed countries. This sector displayed an export peak at the time of selecting our sectors (early

\footnotetext{
${ }^{6}$ A more thorough description of these four case studies is provided in Artopoulos et al. (2011b).

7 This sampling method, known as theoretical sampling (Glaser and Strauss, 1967, Eisenhardt, 1989), can yield more illuminating results than random or stratified sampling when the research purpose is to obtain new insights about an unexplored phenomenon rather than test statistically a specific theory that attempts to explain it.

${ }^{8}$ These sectors are displayed in Appendix Tables A.1 and A.2, respectively. Appendix A describes our procedure in further detail.

${ }^{9}$ Although Rauch (1999) classifies wines as reference-priced, most wine exported from Argentina is a differentiated product.

${ }^{10}$ An exception was made in the case of motorboats, which reported exports in 2005 slightly below 10 million U.S. dollars.
}

2006) and hence passed our statistical criteria. However, exports to the OECD consisted only of a temporary surge. From 2000 to 2008, $96 \%$ of export growth in the sector is explained by increased sales in Latin America.

Our fieldwork was conducted over an eight-month period between May and December of 2006. A few follow-up interviews and phone calls were made afterwards. In total we conducted 40 interviews. While fifteen of them were conducted with the owner or general manager of a firm, the rest were done with relevant actors in the industries studied. Appendix Table A.3 provides detailed information about the interviews we conducted. The interviews were semi-structured using open-ended questions that varied according to the person interviewed and the degree of advancement of our study. The interviews were conducted in Spanish and generally lasted approximately one hour and a half. In most cases, they were conducted at the production facility of the firm and were accompanied by tours of these facilities. All interviews were digitally recorded.

\section{Description of case studies}

This section describes the process of export emergence in the wine, television program, motorboat and wooden furniture sectors in Argentina. Each case first describes the export emergence phenomenon in the context of world trends in the industry. Then, it illustrates the business practices that firms had to change in order to establish a consistent presence in developed markets. Finally, it recounts the business history of the export pioneer, when there is one, and the emergence of other exporters in the industry. All of the sectors except wooden furniture were found to have an export pioneer that led the emergence of exports in his respective sector. Appendix B describes the macroeconomic context of these case studies and the evolution of Argentine exports of differentiated products over the corresponding period.

\subsection{Wines}

Until a Chardonnay and a Cabernet Sauvignon from the United States won a famous wine tasting competition in Paris in 1976, French wines had dominated the high-quality market for this product. The "new-world" style of winemaking behind these two wines enabled countries from all over the world to begin shifting from the production of customarily low-quality, old-world wines to higher quality, newworld ones. The emergence of such wines led to a decline in the worldwide market share of France. Between 1995 and 2008, this share decreased from $48 \%$ to $34 \%$. In contrast, the market share of wines originating in the new world, namely countries outside of Europe such as Australia, the U.S., Chile, South Africa, and Argentina, increased from $16 \%$ to almost $39 \%$. The advent of new-world wines was driven partially by the emergence of new wine consumers in countries such as the United States, the United Kingdom, Australia and New Zealand. The emergence of these new consumers was accompanied by a shift in traditional wine-drinking countries such as France, Italy and Spain away from table wines made with traditional, old-world techniques, toward beer and new-world wines. Hence, even while the number of liters per capita of wine consumed in these countries was declining, the consumption of new-world wines continued to increase. The U.K. and the U.S. are the largest importers, representing $17 \%$ and $14 \%$ of total wine import value respectively. Germany, Belgium and Canada are the next three largest importers. These five countries accounted for more than half of total imports of wine in 2008.

Until the early 1990s the vast majority of wine production in Argentina was dedicated to the domestic market and no wine was specifically adapted to be sold abroad. After knowledge of how to make new-world wines spread throughout the sector, exports increased dramatically rising from US\$ 25 million in 1993 to US\$ 646 million in 2008 (Fig. 1). During the same period the number of countries to which Argentina sold its wines rose from 45 in 1993 to 115 in 2008. This diversification 


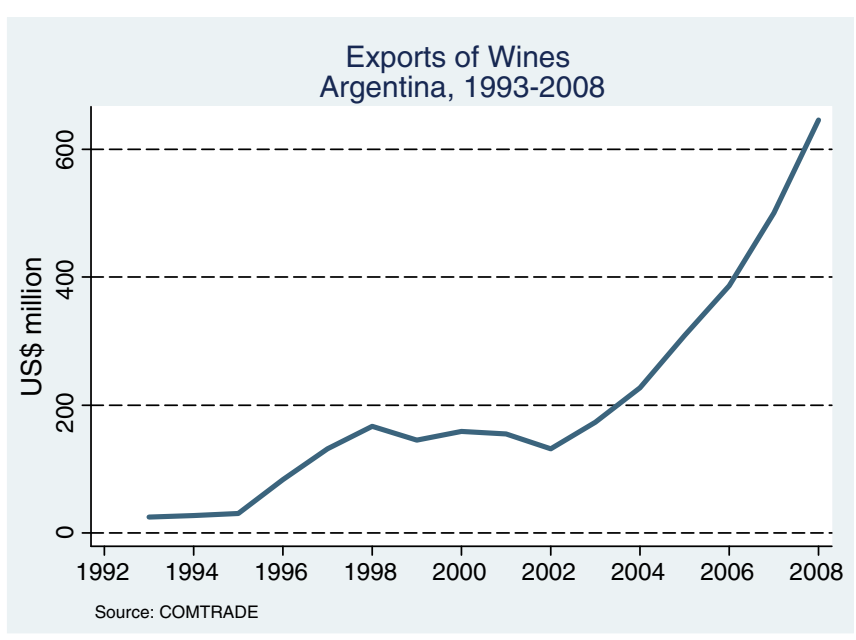

Fig. 1. Exports of wines: Argentina, 1993-2008.

was accompanied by a remarkable shift in destination markets. While Latin America had accounted for $2 / 3$ of exports in 1993, this same share of exports was accounted for by OECD countries in 2008. By that time Argentina had become the tenth largest exporter of wine in the world, capturing slightly over $2 \%$ of the world market.

The wine industry in Argentina originated in colonial times and largely focused on the production of old-world, fine wines. By the 1940s the production of less expensive and less elaborated table wines began to replace the making of fine wines. Until the 1980s few winemakers had traveled abroad with the intent of improving their wines. Nevertheless, a handful of wineries began experimenting with elaborating new-world wines during that decade. Their number was limited because price controls combined with high inflation and government subsidies for producing less expensive wines made experimenting with high quality wines a relatively unattractive endeavor. Once the Argentine economy stabilized and liberalized in the 1990s, many wineries updated their machinery and began undertaking such experiments.

Before the 1990s the vast majority of wineries in Argentina used traditional old-world techniques for making wine that did not require them to have any scientific understanding of either the way grapes were grown or wine was made. Decisions about planting, harvesting and fermenting were based almost solely on tradition. At the same time, all except a handful of winemakers were unaware of the transformation that had occurred with the advent of new-world wines and therefore they did not know how to adapt their wines to meet the changes in tastes in the developed world. Even fewer of them knew how to develop effective marketing campaigns or how to work with distributors in these countries. In order to export successfully on a continual basis, wineries had to change the way they did business in all of these areas.

The taste of new-world wines was dramatically different than the traditional table wines made in Argentina. These wines are more sophisticated and elaborated than traditional old-world ones and require a careful attention to quality. The challenge was complicated not only by the fact that there were initially no domestic consumers of this product but also by the fact that the intricacies of the tastes of drinkers of new-world wines across the world differ and change over time. For example, although new-world wines are generally fruiter, more aromatic, lower in alcohol content, and less aggressive on the palette than old-world wines, U.S. consumers prefer more aging in oak barrels, while European consumers prefer wines with higher alcoholic content. A new-world wine that wins a prize in one country can be deemed rough by consumers elsewhere. Consequently, wineries had to understand these differences, while at the same time tracing how tastes in each country changed. Many times they hired international consultants in this field, "flying winemakers", to help them understand and satisfy these different and changing tastes.

To meet the higher standards of consumers of new-world wines, new types of grapes and new kinds of wine had to be produced. This implied abandoning traditional artisan ways and embracing scientific methods developed by new-world producers in other parts of the globe. The new-world way of making wines requires vineyards to grow skinny grapes with little liquid, instead of the large, juicy ones used for old-world wines. Wineries also have to upgrade their operations by focusing more on quality and less on quantity, and undertake careful scientific studies of land to see which type of grape best suits its characteristics. Argentina is particularly well suited to meet a variety of demands in terms of taste because its soil can accommodate 28 different types of grapes.

At the same time, the method in which wines are made was dramatically altered with the introduction of new machinery such as stainless steel tanks. They enable enologists to control the exact temperature at which fermentation occurs. Enologists have to oversee the day-to-day operations of the fermentation process, while at the same time cooperating with agronomists to ensure that the vineyards they use will yield the type of grapes desired. They bridge the gap between what is desired by their winery's clients and what is physically possible given the available raw materials. Enologists often seek the help of flying winemakers to help them introduce the appropriate changes in their wineries and vineyards. Wineries seeking to make the transition to the production of new-world wines have to make significant investments in equipment such as refrigeration systems, grinding centrifuges, numeric presses, pumps, stainless steel containers, and 225 liter oak barrels. Many wineries in Argentina continued to use old-world production techniques and focus on the domestic market well throughout the 1990s. They were interested in volume rather than taste and therefore tended to over irrigate their fields, creating higher producing grapes with less concentrated flavors and lower quality.

Even if a winery understands what types of wine it has to produce and how to produce them, it will have difficulty selling new-world wines abroad if it does not understand how to work with distributors and how to market its products in foreign countries. The limited number of wineries that had previously sold old-world wines abroad before the introduction of new-world techniques in Argentina generally sold their product as a commodity and therefore did not have to work closely with distributors. New-world wineries that successfully export their wines to the developed world know that the practices they use on the domestic market will not work with international distributors in these countries. Unlike in the domestic market, these firms work closely with distributors and pay careful attention to their specific demands regarding issues such as back-office procedures. For example, they know that international distributors in developed countries do not accept renegotiating terms and conditions, a common practice in the domestic market. These international buyers also expect certain basic marketing practices. For instance, wineries have to design labels that inform customers about the region where a particular wine was made and the general characteristics of its flavor. They also have to ensure that the labels on their bottles do not peel off and that the boxes that contain them are not damaged and come with proper markings. These practices initially represented challenges for wineries, as domestic distributors did not have such requirements. Nevertheless, if wineries proved capable in making these changes, they often found that their distributors were willing to help them keep up to date on evolving trends. To sell wines in the developed world wineries have to put advertisements in international wine journals and not solely in general magazines as is the practice on the domestic market. Wineries that want to export also have to develop an icon wine, an expensive wine that demonstrates their capabilities. Although the expected profits from such wines are generally low due to their limited turnover, they are used as a marketing tool to promote the less expensive wines in a winery's portfolio. 
Nicolás Catena Zapata was the first Argentine wine producer to systematically adopt the practices outlined above. He was also the first to achieve consistent sales of new-world wines to developed countries and the first to sell an icon wine in a developed country for a price of $\$ 80$. His winery was also the only one to achieve unabated export growth to the OECD from 1994 to 2006. His efforts to develop a newworld wine made in Argentina began after he returned from a threeyear stay at the Department of Agriculture and Resource Economics at U.C. Berkeley in the early 1980s where he taught basic microeconomics as a visiting professor under the auspice of a former classmate at Columbia University. During this time he visited a number of wineries in Napa Valley, befriending winemakers that had developed and mastered new-world winemaking techniques. One of the most important acquaintances he made was Robert Mondavi, one of the leaders of the new-world wine revolution in California.

Nicolás Catena Zapata had taken control over his family winery in 1963 while he was doing a PhD in Economics at Columbia. He traveled back and forth from New York to Mendoza, the center of wine production in Argentina, on a regular basis during his studies. By 1980 his winery was one of the largest in the world, selling $38 \%$ of the wines consumed in Argentina. A few years later he had sold most of his family's wineries, while retaining the highest-quality one. He used the knowledge he gained in California to totally revamp his high quality winery to make new-world wines. According to Nicolás, his decision to undertake this transformation was not based on a detailed economic analysis of potential markets but rather on a desire to emulate the success he had witnessed in the United States. The first wines he exported from Argentina in the new-world style were a Chardonnay and a Cabernet Sauvignon. He specifically chose to make these two types of wines because they were the same varietals that had won the tasting in Paris in 1976. After making these wines, Catena realized that it was critical to work with wine journalists to promote his products and that he needed to lead the promotion efforts himself. Part of his marketing campaign included contracting two of the best Argentine tango dancers and traveling to various cities in the United States, his primary target market. He decided to use tango dancers because it was practically the only cultural icon from Argentina that people in the United States knew and he wanted them to associate the quality of his wine with the quality of these dancers.

The boom in the number of wineries that began to adapt new-world production techniques began shortly after Catena sold an icon wine in the United States in 1997. Although the growth in exports would dramatically increase after the currency devaluation in Argentina in 2002, the ability of Nicolás Catena Zapata to make an icon wine in Argentina that was highly praised in the United States by such prestigious trade magazines as the Wine Spectator led to a dramatic influx of foreign capital into this industry. According to Catena Zapata, he set the model to be followed even for well-known multinationals like Chandon, one of France's largest producers of wine and champagne ${ }^{11}$ :

"They (Chandon) followed me in everything I did. They confessed that they copied me even in the places where I bought new vineyards".

Peñaflor, one of the most important wineries in Argentina, began to export Trapiche, one of its most traditional wines, in 1965. However, this wine was not tailored to the tastes of markets in the developed world. It was remade according to new-world standards only after this winery was fully bought out by Donald, Lufkin and Jenrette, an international investment group, in 2002. Besides changing the wines made at Peñaflor, this investment group also dramatically transformed the winery's back office procedures. Only in 2005 did Peñaflor export more wine in terms of overall value than Catena Zapata. Like Peñaflor,

\footnotetext{
11 "Me siguieron (Chandon) totalmente. Me lo confesaron que me seguían hasta donde yo compraba las viñas."
}

two of the other top exporters in this sector were companies owned by international investors. One of these wineries, Norton, began its transformation in 1989 when it was bought by an Austrian investor. The other international winery, Trivento, was opened in Argentina by the Chilean winery Concha y Toro in 1997. One of the earliest followers was the domestic winery Familia Zuccardi. Although this winery also experimented with new-world wines in the 1980s, it consistently lagged behind Catena Zapata in terms of quality and price. Domino de Plata, another leading domestic winery, was cofounded by Pedro Marchevsky, the enologist that led the transformation of Catena Zapata's wineries.

\subsection{Television programs}

The international market for television programs was transformed significantly with the advent of formats in the 1990s. This novel product offered a new set of countries the opportunity to participate in a market traditionally dominated by the United States. Formats are essentially the idea, main structure and salient features of a television program. Unlike traditional canned programs, they are not designed for the audience of a particular country. Instead, formats are designed to be adapted to the cultural idiosyncrasies of different countries. This flexibility enabled formats to capture a substantial portion of the television market worldwide. Between 2001 and 2004, the number of shows using formats grew by a third and the broadcasted hours of programs based on format expanded by $22 \%$. From 2004 to 2008, worldwide sales of formats went from 6.4 to 9.3 billion Euros (FRAPA, 2009). The advent of formats enabled European companies to significantly challenge the international dominance of the U.S. in this industry. Great Britain is currently the leading exporter in this sector, with 98 formats exported in 2008, followed by the U.S. with 56 and the Netherlands with 23 . Half of the formats exported are game shows, while the other half consists predominantly of reality and talk shows. Although fiction formats are a relatively small portion of the industry, it is the most important genre of format exports from Argentina.

Despite a long tradition in creative filmmaking, until the 1990s exports of television programs made in Argentina were limited. During the first half of the twentieth century, the country had been a successful exporter of films, selling them mainly to Spain and Latin America. However, until the last decade of that century, exports consisted largely of a small number of soap operas sold to other countries in Latin America, Spain, and nontraditional markets such as Russia and Israel. Exports were limited because in general Latin American soap opera viewers did not find the Argentine Spanish accent appealing. The emergence of formats enabled Argentine firms to overcome this problem. Independent production companies that had emerged from the privatization of the television industry in Argentina during the early 1990s were the first to take advantage of this new opportunity. Later, multinational production companies acquired a number of domestic companies to serve the domestic and foreign markets.

Argentine television exports span the whole range of related services, from selling format rights to consulting and production services. Official statistics for exports in this industry are difficult to obtain because they are not processed through customs. Consequently, the value of TV-format exports can only be estimated. Exports of audiovisual services, the general category that encompasses television formats, have increased from US\$ 17.5 million in 1996 to US\$ 304.7 million in 2007 (see Fig. 2). Between 2006 and 2008 companies in Argentina exported 59 different versions of 26 original formats. Nevertheless, the actual revenue from activities in this sector is difficult to estimate as consulting services are the most lucrative part of this business and reports of such activities fall under a general category that includes a number of other businesses. Between 2006 and 2008 producers of formats in Argentina exported their products to 15 different locations worldwide.

Although formats are usually first used in a firm's domestic market, unlike traditional television programs they are designed from their 


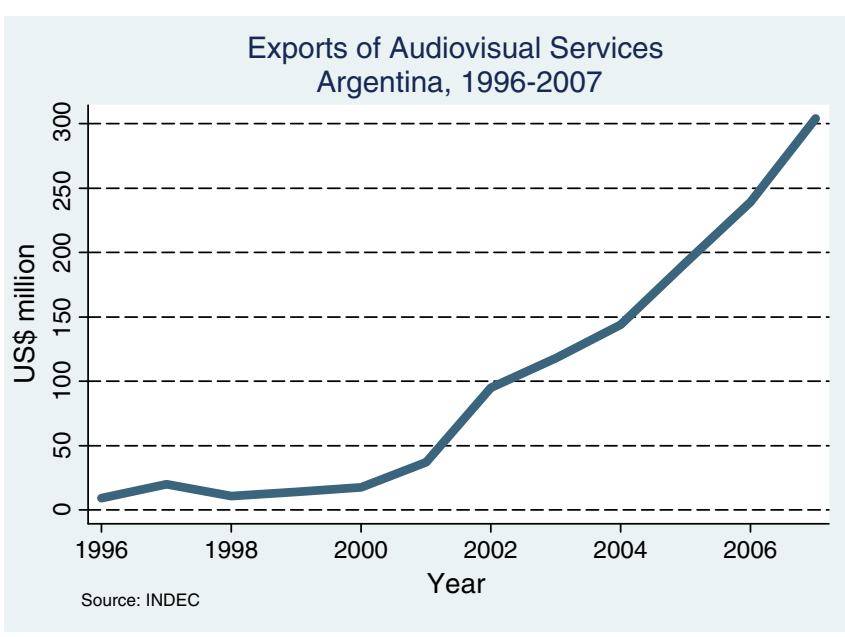

Fig. 2. Exports of audiovisual services: Argentina, 1996-2007.

inception to be exported. The design and production of formats are radically different from how these activities are performed for traditional programs. The making of a television program based on a format is divided into two distinct parts, the creation of the format and its adaptation and production for a particular country. The former involves the creative activities in designing the structure, the plot, and the themes to be covered. The latter encompasses adapting the script and producing the actual program adding critical idiosyncratic elements specific to the market in which the program is to be aired. Essentially, formats are designed to be filled with different cultural content. This sector differs from the others discussed in this study because it involves the design of a generic product followed by its customization to the idiosyncrasies of the target country in the production process. Not every successful television program can be turned into a format. Desperate Housewives was a failure in Argentina largely because this country lacks the typical suburban middle-class housewife on which this series is based. In contrast, Argentina's Montecristo has been a success worldwide because it has neither culturally specific characters nor culturally specific plot components. The separation of design and production in a format requires programs with a strong structure so that they can be easily adapted to the cultural idiosyncrasies of other markets. By contrast, the design and production of a traditional program oriented to the domestic market are inherently intertwined because key design decisions need to be made when the program is being filmed. According to a top manager of one of the exporting companies, domestic firms often appear to be unaware of the need to adapt programs to foreign markets ${ }^{12}$ :

“...they try to sell the same (programs) abroad that they sell here... and it is not like that. You need to pay your dues, get to know what the other one likes. Television is not the same in every country".

When producing formats, firms systematize different aspects of the production process. In fact, the rights to a format include a full set of specifications from the dressing of actors and hosts to specific features of illumination and editing. Those specifications need to be clear so that they can be easily applied by production crews in other countries. When a firm produces a format in a foreign location, it has to coordinate the activities of a variety of local and foreign suppliers. Traditionally programs were made entirely within the four walls of the firm. Furthermore, firms that export often require the assistance of specialized consultants, as information about specific cultural traits can be extremely

12 “....intentan vender afuera lo mismo que hacen acá...y no es así. Tenés que pagar un derecho de piso, saber qué es lo que le gusta al otro. No es la misma televisión en todos los países. tacit and therefore difficult to obtain for a company seeking to produce a format for a foreign country. Finally, firms that successfully export formats also need to upgrade some parts of the production process. For example, Promofilm made an important investment in editing equipment to produce formats.

Companies in Argentina export formats by selling them directly to potential clients through their own sales offices, commercializing them through international brokers or merging with an international company. To pursue any of these options firms need to have a strong reputation. Trade fairs such as the Cannes Marche International des Films et des Programmes pour la TV, la video, le Cable et les Satellites (MIPCOM) and the meeting of the National Association of Television Program Executives (NATPE) are venues in which companies can draw on their reputations to meet new or existing clients, while keeping themselves up to date on new trends. Firms often try to build their reputation by providing better-known firms critical services in adapting a format to a particular country.

Horacio Levin was the first person to consistently export formats to developed countries and the most important one in leading the transformation of business practices in this industry. He began his company, Promofilm, as an importer of cartoons and animated films. During this stage of his business he developed international contacts by traveling to international trade fairs on a regular basis, an unusual practice in this industry at that time. Before beginning to design formats, he imported them from other countries and adapted them to the Argentine market. Levin bought his first format, Sorpresa y media, from a Spanish company. Later, he sold this program to television channels in Brazil, Colombia, Ecuador, and Venezuela. At the same time, he was training many individuals that would later become critical managers in other television production firms. Levin was not the actual owner of CQC (Caiga Quien Caiga), the first format to be exported from Argentina in 1996. However, he played a critical role not only in convincing the owners of this program that it was possible to export it as a format but also in actually facilitating its sale to his Spanish associates at Globomedia. Promofilm began working with Globomedia in 1995. The Spanish company acquired a fraction of Promofilm in 2002 and completed its acquisition in 2005. Levin's years of experience in this industry led him to believe that associating with a Spanish company was the best way to compensate for the fact that Argentina lacked international credibility in the television industry. According to Levin, his new partners would also serve as a source of information about evolving trends ${ }^{13}$ :

"My Spanish partners kept me abreast of what was happening in the world, we were (in Argentina) far from the world".

In 1998, the two companies jointly bought the format rights for the Swedish reality show Expedition Robinson, known as Survivor in the United States. Each partner adapted it to their respective countries. Promofilm would come to open a production facility in the Caribbean to produce this program for a number of countries including Russia, Hungary, Italy, the United Kingdom, and other South American countries. The first new format that Promofilm created, Protagonistas de Novela, was exclusively developed for Telemundo in the United States. It would later be exported to Greece and five Latin American countries without ever being sold in Argentina. In 2005, Promofilm Globomedia was bought out by Grupo Arbol, a Spanish media conglomerate.

Levin's actions in this business convinced other firms, including multinationals, that firms located in Argentina were capable of successfully exporting formats on a consistent basis to the developed world. Horacio Levin actively promoted the diffusion of his knowledge about the format business in Argentina. The real growth in this industry would not occur until the first few years of the 21st century when multinational companies, following the precedent set by Levin, began

\footnotetext{
13 "Mis asociados me mantenían al tanto de lo que pasaba en el mundo, nosotros (en Argentina) estábamos lejos del mundo."
} 
merging with domestic ones. For example, in 2001 Endemol, a Dutch company founded in 1994, acquired a 65\% stake in P\&P, an Argentine producer of formats while, in 2007, Dori Media bought 50\% of Central Park Productions. Telefé, a Spanish company that owns a television station in Argentina, started by importing and adapting formats to the Argentine market. After the success at adapting international formats to Argentina's domestic markets, it started to create its own formats and sell them abroad.

\subsection{Motorboats}

The motorboat industry has largely been dominated by producers in developed countries selling to consumers in these countries. Throughout the late 1990s this industry had primarily consisted of small- to medium-sized firms that used small-scale production facilities to make boats for specific market niches. By the beginning of the $21 \mathrm{st}$ century many of these firms began to merge into larger business groups that abandoned small batch production for niche markets and switched to making mass-produced, relatively large boats, for a broader market. The vast majority of the producers and exporters of motorboat are located in the developed world. The largest exporters in 2008 were Italy (25\%), Germany (16\%), the United Kingdom (15\%), and the United States (12\%). Consumption and imports are also highly concentrated in the developed world. These countries accounted for $92 \%$ of all motorboat sales in 1996 (E Composites, 2006). The consolidation of this industry offered firms located in developing countries such as Argentina a chance to compete in market niches that were left relatively underserved by these new business groups. One such underserved market niche consisted of medium-sized motorboats, the market segment targeted by Argentine firms.

Argentine firms find exporting particularly challenging because almost all boats sold on the domestic market are designed for fresh water, while the demand for medium-sized boats in the developed world is almost exclusively for salt-water vehicles. Fresh-water boats cannot be used in salt water because their hulls corrode quickly if they are exposed to salt. Salt-water boats are uncommon in Argentina as the vast majority of motorboats are used in the River Plate, the widest fresh-water estuary in the world. Given that a significant proportion of the Argentina population lives in Buenos Aires, a city located along the River Plate, the vast majority of boats in Argentina are designed to be used on day trips. By contrast, boats bought in the developed world are generally designed to be used on longer trips, and hence are customarily equipped with amenities to ensure comfort in such excursions.

Before the late 1990s, firms in this sector concentrated almost exclusively on the domestic market. Exports were rare and sporadic. By that time, sales abroad began to increase significantly, reaching US\$ 3 million in 2002 and US\$ 15 million in 2007 (see Fig. 3). Even though important parts such as engines are still imported, exports were helped by the devaluation of the Argentine peso in 2002. In 2008 exports declined due to the world economic crisis that began in that year. This crisis disproportionately effected the consumption of luxury goods. Three out of the five largest importers from Argentina are OECD countries: Spain (17\%), Italy (15\%), and the United States (12\%).

Firms in this sector that export consistently to the developed world adjust their production capabilities to make products designed specifically for these markets. Besides making sturdy, comfortable boats that resist corrosive salt water, successful exporters in this sector design and engineer their boats to meet the demands of customers in these markets. They also incorporate distinct luxury items (e.g. expensive speed gages) designed by companies such as Porsche and Ferrari into their boats for export as this type of add-on is sought by consumers in these countries but not by domestic consumers. Successful exporters know that they have to meet the challenging demands and idiosyncrasies of the countries to which they export in the developed world. Thus, they continually change the design and furniture of their boats to meet changes in the market. For example, consumers in these countries have

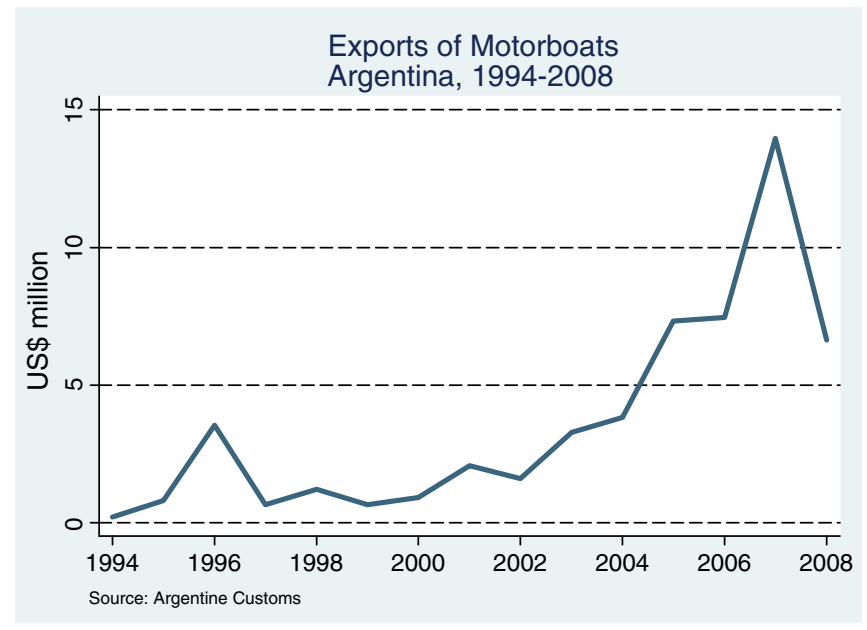

Fig. 3. Exports of motorboats: Argentina, 1994-2008.

recently started to demand interior furniture with rounded shapes that are made of pale wood, instead of the dark, square furniture that was common in the past. They have also begun demanding a greater number of appliances, better quality materials in the interior parts of their boats and frameless windows instead of traditional portholes. New firms from a developing country cannot expect to compete with top brands such as Azimut and Ferretti because brand reputation is a key element in the purchasing decision of traditional luxury consumers. However, they can address specific niches with less well-known brands. Although brand reputation is also important in the Argentine market, consumers in this country are far less demanding in terms of add-ons and interior designs.

Successful exporters employ designers who understand the tastes and needs of foreign markets and can design boats that meet those tastes and needs. For example, they frequently use stainless steel fenders instead of plastic ones and engrave the brand's name in steel rather than simply painting it on the deck as is customary on the domestic market. Unlike in this market, boats that are exported require detailed junctions and corners to meet the requirements of customers in these countries. Although producers of these boats in the developed world rely on serial production using standardized matrices, such standardization is not necessary for the Argentine market because local consumers tolerate the imperfections that occur with artisan styles of production. Exporters from Argentina do not have the sales volume to justify serial production and standardized matrices. Instead, they use computeraided design (CAD) to help them design their products in a way that enables mistakes to be reduced in the production process. At the same time, exporters to developed countries rely on foreign suppliers for parts such as propellers and axles because quality suppliers of these parts are difficult to find in Argentina and their international clients have quality expectations higher than those on the domestic market. They also use standardized components such as electrical circuits and provide their clients with detailed technical information so that their boats can be worked on by technicians in any part of the world.

In order to keep up on trends, owners of firms that export to the developed world often attend international boat shows in Genoa, Venice, and Barcelona. They provide information about these trends to their designers and engineers so that they can tailor their products to the new needs of specific countries and market niches. Going to these shows also gives these owners a chance to create new business relationships or build on previous ones. One of the reasons why successful exporters of boats from Argentina tend to work with a limited number of suppliers and journalists is their desire to maintain a constant flow of information. These firms also have to pay careful attention to differences in ways of marketing between the domestic market and the developed world. 
While firms that sell their boats on the domestic market use the name of the founding family as the company name, companies that export tend to change their brand names so that they are more appealing in foreign advertisements.

Luis López Blanco was the first individual to export consistently to the OECD. The company he founded, Compañia Constructora de Embarcaciones (CCE), has been the largest exporter to the OECD in this industry since 2000. He has exported his boats to Germany, France, Italy, Spain, Norway, Greece and Venezuela. López Blanco was formerly a local representative of foreign brands of motorboats and motorboat engines and did not have any background in production. He founded CCE in 2000 with the explicit goal of exporting boats from Argentina. He applied the knowledge of foreign markets he had gained during his time as a local representative of foreign brands by focusing on mid-sized boats. He learnt about foreign markets by going to corporate meetings as a distributor of Cummings motors and Azimut motorboats. Later, at boat shows, he developed key relations with distributors and sellers. To produce a boat for markets in the developed world he used plush interior designs and instruments, applied the latest production techniques, and worked closely with foreign distributors. Sometimes finding that traditional input suppliers in the motorboat industry were not responsive to demands for quality upgrading, he resorted to suppliers from other industries for needed parts, such as windshields, aluminum pieces, and CAD/CAM services. His first model, called Aqualum 35, was developed in 2000 with the aim of emulating industry leaders such as Azimut and Ferretti. Unlike the boats produced by other domestic firms, the Aqualum 35 was equipped with Italian appliances. The rationale behind the use of imported appliances was not only to employ premium brands, but also to set foreign customers at ease by providing appliances that they already recognized and trusted and that could be easily replaced or repaired. In a similar vein, he decided to use the Latin word Aqualum as his brand in order to appeal to consumers throughout Europe. López Blanco was aware that people in Europe may be hesitant to buy such a big ticket item from a country with no international reputation in this industry. Hence, he took various actions to confront this disadvantage. For example, he decided to temporarily sell his boats abroad below cost and to add quality assurance services that were new to Argentina's industry. On one occasion he even decided to send a technician to the United Arab Emirates to rework an instrument panel for a client who was unsatisfied with it. His efforts to avoid this type of concerns were broad ${ }^{14}$ :

"We imitated the style of our Italian distributor in things such as the technical data, brochures, and even our personal appearance, ...we took care of our clothes, ... to be like one of them (...) we offered a product similar to theirs, with a clear Italian orientation, equipped with international appliances, ...there are no surprises, one lifts the lid of the engine room and the engine room looks like that of any boat from there."

While the median number of exporters per year during the 1990s was only one firm, this number had reached eighteen by 2006. Nevertheless, the two largest exporters, CEE and Altamar Yachts, accounted for more than $50 \%$ of total exports in this industry. Like CEE, Altamar Yachts was founded with the explicit purpose of focusing on the export market, even though it originally focused on MERCOSUR countries. Its first successful export to a developed country occurred in 2003. This company is not only the largest exporter overall but also exports more to OECD countries than any other firm. Similar to Altamar, Klase A also

\footnotetext{
14 "Nos presentamos con el mismo estilo de nuestro distribuidor, los datos técnicos, un folleto parecido al de ellos, en nuestro aspecto tratamos de parecernos a ellos, cuidamos nuestra vestimenta, (...) para parecernos a uno de ellos (...) llevamos un producto parecido al de ellos, con clara orientación italiana, con todos los equipos internacionales, no hay sorpresas, uno levanta la tapa de la sala de máquinas y parece la sala de máquinas de cualquier barco de allá."
}

started by exporting to countries in MERCOSUR. Nevertheless, it did not make its first sale to an OECD country until 2004. All three of these firms believe that the emergence of new exporting firms would be beneficial for their own company because it would enable Argentina to gain greater recognition as a reliable producer of high quality boats. In fact, when he was chair of the chamber of commerce for this industry, Lopez Blanco actively tried to convince other firms of the importance of changing their business practices in order to export. Nevertheless, the pay-off for his efforts has yet to be realized.

\subsection{Wooden furniture}

Although exports from the wooden furniture sector in Argentina doubled during the 2000s, Latin America was responsible for $96 \%$ of this export growth. Unlike the other three sectors, sales to developed countries only witnessed temporary growth. Toward the end of the 2000s exports from this sector had fallen back to their previous levels (see Fig. 4). Developed countries are the largest worldwide importers in this industry, with the United States accounting for almost $20 \%$ of world imports. On the export side, Italy had long been the largest exporter until China overtook it in 2004. By 2008 the ten largest exporters included both developed nations such as Germany, Denmark, the U.S., and Canada as well as countries with relatively low wages such as Vietnam. Nevertheless, Italy continues to be the country that exhibits the highest export unit value. It retains this position by relying on flexible machines and skilled workers to produce quality products instead of using automated machines to produce standardized furniture, as is the case in lower income countries. Despite the fact that Argentine manufacturers would face significant difficulties competing with the quality of furniture made in Italy or with the low price of standardized furniture from countries with inexpensive labor, an opportunity for them seems to be present in a new medium-quality market segment of contemporary furniture. This segment emerged in the 1990s, and consists of customers who buy stylish furniture that is not mass-produced but which is not as expensive as higher-end products.

Although Argentina has a long history of producing furniture for its domestic market, exports were practically nil until the 1990s. Traditionally, firms in Argentina only exported furniture when the local market was declining, limiting their exports to products designed for this market. Only in the first few years of the 21st century did some Argentine firms begin adapting the designs of their products for the developed world. In the 1990s the vast majority of firms took advantage of the convertibility plan to buy sophisticated, flexible machinery that could be used to semi-customize products. The use of flexible machinery enabled these firms to quickly alter their production processes to make products in new sizes and dimensions. Thus, they could adapt their production to keep up with trends in markets like the U.S., the developed country

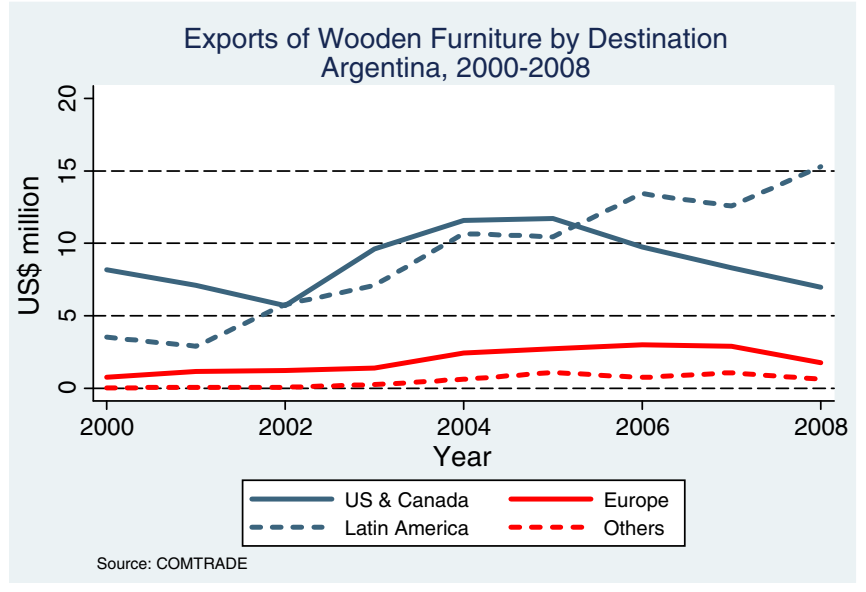

Fig. 4. Exports of wooden furniture by destination: Argentina, 2000-2008. 
that accounts for the majority of exports from this sector. Unlike the vast majority of firms in other countries that export wooden furniture, Argentine producers do not need to import wood.

Some companies understand the differences, albeit usually slight, between the tastes in Argentina and those of countries like the United States. For instance, furniture in the latter country tends to be larger than in Argentina because houses are generally bigger. Differences in tastes can even exist between different regions in the United States. For example, consumers on the west coast prefer darker stains, while those on the east coast prefer lighter ones. Some companies that exported to the United States kept up to date on trends in this market because they knew that U.S. consumers of contemporary furniture change the furnishing in their houses on average once every five years. Changes in style are much less common in Argentina, where on average customers change their furniture only once every thirty years. Variations in styles in the United States can be rather subtle. For example, when flat screen televisions first appeared in that country, families wanted furniture to accent this appliance. Now that such products are ubiquitous, they want furniture that hides it. One Argentine firm keeps up to date with such changes by contracting international consultants. Another firm actually sent their designer to Italy to take courses on design so that she could learn to adapt furniture to tastes in the developed world.

Some firms in this sector introduced changes in their production processes in order to satisfy quality standards of consumers in the developed world. None of the firms that we interviewed actually bought new machinery or contracted workers with better skills in order to meet these standards. Instead, the firms that upgraded their production generally did so by just improving the lighting of their facilities and ensuring that their workers paid careful attention to how they performed their tasks. Workers need to pay careful attention to what they are doing and have the light necessary to carefully observe their actions because the quality standards of consumers in developed markets are higher than those in Argentina. For example, measurements for furniture exported to the developed world have to be exact and staining has to be consistent. These attributes are not important for furniture sold on the domestic market. In general furniture factories in Argentina are poorly lit, thereby limiting the ability of workers to pay close attention to what they are doing. Even experienced managers seem notably unaware of the attention consumers and distributors pay to these details in the developed world.

Distributors of contemporary furniture look for potential partners that can build products that they are seeking rather than looking for finished products on the market. Once they establish a relationship with a producer, they help them by providing insights on how to improve their goods. Although companies that value such input invest time in building relationships with their distributors, most firms in this sector are unwilling to make such a commitment. Similarly, trade fairs in this sector were traditionally instances for wooden furniture manufacturers to actually sell their products. Now they are more oriented to providing firms opportunities to learn about recent shifts in tastes and become acquainted with distributors. Only a few Argentine firms value participating in design competitions at trade fairs such as the biannual one in High Point, North Carolina. Those firms design and manufacture a new piece of furniture specifically for this event. Even if firms make all of these changes, they will not be successful in selling their furniture in the developed world unless they carefully obey the letter of their contracts, be they formal or informal agreements. This type of behavior proves challenging for many firms because in the domestic market they are accustomed to loosely interpreting any type of agreement. Many firms even seek to renegotiate the terms of their already-signed contracts. In contrast to foreign markets, distributors in Argentina are accustomed to their suppliers delaying shipments and attempting to change the terms on which they are paid. Firms that seek to export on a consistent basis to developed markets sometimes go to extravagant lengths to overcome the negative image Argentine firms have in this sector. One company actually opened a warehouse in Los Angeles because the only way some of their distributors would buy furniture from this company was if they could inspect their products personally and take immediate delivery.

Prominent firms and associations in this industry contend that Jorge Etchebehere, a commercial agent, is the person who knows the most about how to successfully export to the United States. He is particularly well known for understanding how products need to be adapted to the market in this country. He became interested in the culture of the United States after having participated in a three-month student exchange in New Jersey when he was 16 years old. One of his first jobs in Argentina was working for a company that bought fertilizers and seeds from Monsanto. In this job he acted as an informal cultural consultant for U.S. representatives of this latter company. Later, he would come to work as a foreign sales representative for Genoud, a relative large furniture manufacturer in Argentina. In 1997 he started his own trading company. Through this company he was able to help Fontenla, one of the domestic leaders in this industry, make its first export to the United States. He also assisted another leader in this industry, Mehring, in establishing its first contacts in that country. Together with two U.S. sales representatives he had initially contracted as consultants, Etchebehere formed Argentine Resource Goods (ARG) in 2003 as a means for facilitating exports of furniture to the United States. This company represented eight Argentine firms located dispersedly over the country and operated a warehouse and a 300 square meter showroom in Washington, DC. However, only a few years after it was formed, ARG was dissolved. According to Etchebehere this company failed because many of the companies he represented either did not pay sufficient attention to the type of details in the production process outlined above and/or failed to fulfill their contracts in the manner expected by U.S. buyers. Etchebehere also complained that some of the firms with which he worked did not deliver their products on time. He was not willing to try to obtain the financial resources he would have needed to build his own manufacturing facility.

In 2006, the eight largest exporters in this sector accounted for more than $40 \%$ of total exports. Although each of these exporters had changed some business practices in order to export, none of them had systematically implemented all, or even most, of these practices. Also, unlike in the other three sectors none was able to establish a consistent presence in a developed country. One of the most prominent exporters in this sector, Mehring, made significant changes to the way in which their products for export were designed and produced but failed to establish solid relationships with distributors. Ivope, the largest exporter in this sector, was founded by two Argentines and eventually sold to a furniture producer and retailer of Peruvian origin whom they serendipitously met in Los Angeles, the city in which he was living. Nevertheless, Ivope's export activity is limited to supplying that buyer in the U.S. west coast.

\section{Generalizations from the case studies}

The case studies described in the previous section present a number of common features which constitute the main findings of this study. In this section, we describe these findings. We also discuss their potential determinants, propose hypotheses to interpret them, and relate them to the existing literature.

Finding 1: Consistent exporters adopt a markedly different set of business practices. They also exhibit a common mindset about the importance of adopting these practices and a discourse that suggests that they are mutually complementary.

One of the strongest regularities in our case studies is that consistent exporters of differentiated goods to developed countries (i.e. consistent exporters) implement a new set of export business practices. ${ }^{15}$ These

\footnotetext{
${ }^{15}$ A previous version of this paper (Artopoulos et al., 2011a) labeled this set of business practices "the export business model".
} 
practices are common across the sectors studied but differ radically from those prevailing in the domestic market. We divide export business practices into three groups: "product" practices relate to the identification of the products to focus on, "production" practices relate to the design and actual production of the goods, and "marketing" practices relate to how goods are marketed and sold.

\subsection{Product practices}

In all our cases, we find that consistent exporters design products to match the characteristics of demand in targeted foreign markets. Demand in developed countries is different from domestic demand. Some of the differences originate in these countries' higher requirements for quality and functional sophistication stemming from their higher income. Other differences are due to demand idiosyncrasies of countries. Designing products to match foreign demand requires firms to understand both of these differences. As discussed below, consistent exporters in our cases recognize this need and act consciously to acquire the required knowledge. Furthermore, as demand characteristics evolve over time, they secure information channels for keeping this knowledge up to date. For example, they may hire an international consultant to lay out the basic parameters of a potential product or help local designers introduce adjustments to the products they have designed. Those adjustments are sometimes minimal but are nonetheless critical. By contrast, acquiring knowledge about demand in the domestic market is easier as it does not require an analogous systematic effort.

\subsection{Production practices}

Adapting products to foreign demand requires changes in the production process. Particularly challenging is the need to upgrade quality to satisfy the higher standards of consumers and distributors in highincome markets. While consistent exporters sometimes need to invest in new machinery to achieve this goal, we find in our cases that investment requirements do not generally stand out as the most important hurdle. Instead, the main challenge to upgrade quality seems to be primarily associated with changing production techniques to gain better control of production processes. Consistent exporters pay careful attention to how goods are produced as small defects in the products can lead to their rejection by foreign distributors or even the termination of the business relationship. In the domestic market, such attention is not as necessary since consumers are more tolerant of product imperfections. In some cases, exporters also need to work closely with suppliers and service providers to help them upgrade the quality of their own inputs and services.

\subsection{Marketing practices}

Consistent exporters make great efforts to comply with the business practices of distributors in developed countries. For example, they satisfy their more rigorous expectations in terms of quality consistency and timely delivery, as well as other specific requirements such as packaging and back-office procedures. They also make substantive efforts to convey early signals that they are serious about complying with those practices. In addition, consistent exporters regard their distributors as a resource not only to help them sell their products abroad but also to assist them in understanding how markets are evolving. For branded products, exporters need to develop an advertising strategy to position a new brand in an unfamiliar market. At early stages in the process of export emergence, firms also have to develop a specific strategy to confront the "country-of-origin bias" stemming from the lack of an established reputation in the industry of the country from which they are exporting. ${ }^{16}$

\footnotetext{
${ }^{16}$ Under imperfect observability of a product's quality attributes at the time of purchase, consumers might resort to the level of development of its country of origin as an extrinsic cue of product quality (Bilkey and Nes, 1982; Verleigh and Steenkamp, 1999).
}

Consistent exporters are keenly aware that this set of business practices are dramatically different than those used on the domestic market. Not only do they adopt these practices but also they emphatically point to them as the key to establish a stable presence in developed markets. They also display a common mindset about the way of understanding how to sell products to the developed world and often refer with derision to firms that attempt to export using the business practices that prevail in the domestic market. Consistent exporters in our cases never emphasized a specific practice as the "silver bullet". Instead, they appear to regard the adoption of each one of them as a necessary condition for exporting. In fact, they frequently provide examples about how failure to adopt a single practice (e.g. failing to make a critical product adaptation or deliver a shipment in time) could have jeopardized their entire export venture. The fact that they regard each practice as critical implies that they view them as mutually complementary.

Finding 2: In three of the sectors, an export pioneer, defined as the first individual to implement the set of export business practices outlined above, was also the first to become a consistent exporter. Export pioneers have a knowledge advantage about foreign markets to which they were previously exposed.

In the motorboat, television, and wine industries, one individual (López Blanco, Levin, and Catena, respectively) was the first to implement the set of export business practices outlined above. We define these individuals as "export pioneers". Export pioneers were also the first to make exporting a stable, substantial, and profitable part of their business. Some of the new business practices they adopted were visible to others who at first did not see their logic and often derided their efforts. Later, these three export pioneers became almost unanimously acknowledged in their industries as the key actor associated with the origins of the industry's export emergence.

In the wooden furniture industry, we did not find any individual or firm that implemented the set of export business practices outlined above. However, one individual (Jorge Etchebehere) was often singled out as the person "who knows the most about exporting". While this person displays the mindset of consistent exporters and adopted most export business practices, his export venture was not successful. Being an intermediary and not a producer himself, he failed to establish a quality control system on the geographically dispersed set of producers he represented.

At the time export pioneers implemented the new set of business practices, their distinguishing feature was the possession of a knowledge advantage over industry peers about the characteristics of demand in developed markets and their ways of conducting business. One striking common finding is that all three export pioneers exhibit a personal history with a strong exposure to developed markets in countries that are central to world trade in their industries. Furthermore, two of the export pioneers - Levin (television) and López Blanco (motorboats) were importers in their sectors with no previous production experience. The importing activity involved regular trips abroad, attendance to the most important international trade fairs (in both cases held in Europe), and business and social interactions with foreign producers and distributors. In the case of Catena (wines), he became familiar with the transformation of the wine industry in the United States by socializing with the most important winemakers and other actors in the wine business community in Napa Valley during a time when he was a visiting professor at U.C. Berkeley. Even Etchebehere (furniture) had some, albeit limited, foreign exposure when he was an exchange student in the United States as a teenager and when he served as local liaison of U.S. technical instructors at a U.S. multinational. In all these cases, the foreign exposure of these individuals preceded their idea of committing to an export business. 


\section{Discussion}

\subsection{The importance of adopting export business practices}

Consistent exporters adopt a new set of business practices. They also emphasize the importance of doing it in their own discourse. This finding suggests that adopting these practices is critical for becoming an established exporter to developed countries. Further, the first individuals to do it are also the first to become consistent exporters to developed markets.

Business practices have been emphasized in studies of productivity (Bloom and Van Reenen, 2010) and human resource management (Ichniowski and Shaw, 2003). However, international trade scholars have given little attention to the business practices that firms need to adopt in order to export differentiated goods to developed countries. Although various papers emphasize the need to change production practices - mainly quality upgrading - for exporting to high-income countries (e.g. Brambilla et al., 2012; Hallak and Sivadasan, forthcoming; Iacovone and Javorcik, 2010; Manova and Zhang, 2012; Sutton, 2007; Verhoogen, 2008), no attention has been given to changes in product and marketing practices. In the case of product practices, while we find that consistent exporters need to adapt their products to tastes and needs of foreign consumers in developed countries, models in international trade typically assume that firms export the same products that they sell domestically. In the case of marketing practices, our findings complement an incipient literature that studies the relationship between local producers and foreign distributors. This literature has mainly pointed to problems of matching (Antràs and Costinot, 2011; Blum et al., 2013; Rauch and Watson, 2004) and contracting (Antràs and Foley, 2011; Macchiavello, 2011) but has not emphasized the importance of changing business practices to comply with those of foreign distributors. Also, it does not highlight how firms tap into these distributors as a source of information about foreign markets. ${ }^{17}$

\subsection{The foreign embeddedness of export pioneers as a gateway to acquiring foreign market knowledge}

We found that the three export pioneers in our cases had previous experiences working and/or living in foreign markets. These experiences seem to have played a critical role in enabling them to develop a new mindset about how to approach foreign markets. We do not think that it is coincidental that all three of them had such experiences. Rather we believe that their foreign experience was critical in providing them the knowledge they would need to develop effective practices for foreign markets.

The theory of social networks emphasizes the role that social (or embedded) ties play in facilitating the flow of subtle and nuanced information as well as the transmission of tacit knowledge (Burt, 1992; Granovetter, 1973, 2005; Powell, 1990). ${ }^{18}$ The previous experience of export pioneers in developed countries enabled them to become embedded in the business community of their industries in those countries. They became part, in different forms and degrees, of those foreign networks. Thus, we hypothesize that their foreign embeddedness enabled them to acquire the knowledge necessary to develop the required export business practices. We particularly emphasize the role of foreign embeddedness in the adoption of product and marketing practices

\footnotetext{
17 Based on interviews to U.S. international buyers in the bicycle and footwear industries, Egan and Mody (1992) highlight the importance of complying with distributors' business practices and their role as a source of marketing information.

${ }^{18}$ From an organizational knowledge perspective, Nonaka (1994) similarly argues that "socialization" is the main channel for the transmission of tacit knowledge.
}

since they are based on information and knowledge about foreign markets that is - as we argue below - subtle, nuanced, and tacit. ${ }^{19}$

Designing products to meet foreign tastes in developed countries requires understanding subtle and nuanced characteristics of foreign demand. For example, apparently minor details may determine how stylish consumers in a foreign country will regard specific features of a product design. ${ }^{20}$ This knowledge is essentially tacit and hence difficult to acquire by a producer in a developing country that has no access to the foreign social networks where this knowledge resides. A critical obstacle is the geographic and cultural distance (Kogut and Singh, 1988; Shenkar, 2001) that separates local producers from consumers in developed markets. This distance renders information about these markets difficult to access and interpret. These obstacles are larger for the type of design-intensive consumer goods exemplified in our cases. The appeal of such goods hinges largely on their aspirational value and their ability to engage consumers' emotions. Since emotions and aspirations are shaped by countries' specific cultural traits and collective values, the need to engage them may impose insurmountable knowledge requirements for a typical producer in a developing country.

Tacit knowledge about foreign markets is also required for adopting marketing export business practices. For example, firms need to learn about the business practices of foreign distributors and how to provide signs that they can comply with those practices and become reliable suppliers. Even clear requests for consistent quality or timely delivery are often misinterpreted by producers in developing countries because they are not accustomed to such requests. A potential reason for their misunderstanding is that key information can only be understood in a specific context that needs to be shared by the communicating parties (Uzzi, 1997). Since local producers do not share the same context with foreign distributors, they may fail to understand the importance of satisfying their requests.

Other aspects of export pioneers' background, resources, and personality may also be important for their export success. ${ }^{21}$ However, we emphasize their foreign embeddedness because we consider it the gateway for their acquisition of foreign market knowledge. This knowledge is particularly valuable at the initial stages in an industry's process of export emergence when it is not yet widespread among domestic producers. It is noteworthy that the foreign embeddedness of export pioneers originated in previous activities carried out before they conceived the idea of establishing an export business. Thus, we can treat

\footnotetext{
${ }^{19}$ We use the term embeddedness broadly to describe how the social relations of firms provide them with access to critical information for changing their business practices. We draw on the original conception of this term as developed by Granovetter (1985) in which he describes how social relations in business communities facilitate transactions between different parties. Our findings also relate to the work of Granovetter (1973), Uzzi (1997) and McDermott (2007) showing that a high degree of embeddedness in close-knit networks may hamper innovation due to limited access to non-redundant information whereas, in contrast, innovation tends to come from weaker social ties outside of that network. In a similar vein, export pioneers in our cases establish social ties in a foreign network. Albeit more limited in scope and intensity, those ties outside of their close-knit domestic network allow them to understand how business practices need to be changed in order to export.

${ }^{20}$ We use the term embeddedness broadly to describe how the social relations of firms provide them with access to critical information for changing their business practices. We draw on the original conception of this term as developed by Granovetter (1985) in which he describes how social relations in business communities facilitate transactions between different parties. Our findings also relate to the work of Granovetter (1973), Uzzi (1997) and McDermott (2007) showing that a high degree of embeddedness in close-knit networks may hamper innovation due to limited access to non-redundant information whereas, in contrast, innovation tends to come from weaker social ties outside of that network. In a similar vein, export pioneers in our cases establish social ties in a foreign network. Albeit more limited in scope and intensity, those ties outside of their close-knit domestic network allow them to understand how business practices need to be changed in order to export.

${ }^{21}$ The case of Etchebehere in the furniture industry is an example of an individual who possessed foreign market knowledge but failed, for other reasons, in his export venture.
} 
their foreign embeddedness as exogenous to their subsequent decision to become exporters. ${ }^{22}$

\subsection{Foreign market knowledge versus production knowledge}

Since adopting export business practices may not necessarily improve the performance of a firm in the domestic market, it is not surprising that domestically oriented firms do not do it to operate locally. By contrast, it is difficult to understand why they often maintain their domestic practices when they attempt to export, especially since they could potentially buy the necessary knowledge. For example, firms could hire an international consultant to help them adapt products or upgrade quality. In our case studies, we find that firms often did not hire such consultants because they did not recognize the importance of addressing the different needs of foreign markets. We hypothesize that firms are unaware of the importance of addressing those different needs precisely because they cannot understand the specific ways in which the foreign and the domestic markets differ. ${ }^{23}$ Often these firms make substantive efforts to find export markets for their existing products but do not examine potential export opportunities that would require adapting these products to the needs of foreign clients simply because they are not aware that making those adaptations is critical.

Potential complementarities of export business practices could additionally help to explain why firms often do not upgrade quality or adopt other production export business practices even when they appear to possess the technological and organizational capability to do so. Due to complementarities, the benefits of adopting production practices may not be substantial unless product and marketing export business practices - which depend more heavily on tacit foreign market knowledge - are also adopted. ${ }^{24}$ Finally, complementarities in business practices have also been identified in human resource management (Friel, 2011; Ichniowski and Shaw, 2003) and production practices for quality upgrading (Kugler and Verhoogen, 2012) but they have not been identified in the case of business practices required to export. We think progress on this front can be achieved by designing surveys to inquire about business practices of exporters and domesticallyoriented firms.

Our findings call into question the predominant focus that the international trade literature has placed on productivity as the key determinant of whether firms export (e.g. Arkolakis, 2010; Bernard et al., 2003; Melitz, 2003; Verhoogen, 2008). ${ }^{25}$ While productivity is naturally associated with production knowledge, our findings suggest that the ability to consistently export might be more closely related to the possession of foreign market knowledge. In fact, in our case studies we did not encounter a single case of an entrepreneur or manager who acknowledged the importance of adopting production export business practices e.g. meeting the quality standards of developed countries - but regretted not having the required technological or organizational capability. Rather, we can generally attribute failure to upgrade quality or adopt other production export business practices to an unawareness or insufficient conviction about the importance of doing so. Following on our earlier discussion about the implications of complementarities, the

\footnotetext{
22 The fact that their foreign exposure was not motivated by the prospect of later becoming exporters also suggests that it might be too costly to pursue this experience with the sole objective of acquiring foreign market knowledge.

${ }^{23}$ Experiments in psychology find that people who are incompetent in the strategies they adopt to reach success and satisfaction not only reach erroneous conclusions and make unfortunate choices but also their incompetence robs them of their ability to realize it: "the skills that engender competence in a particular domain are often the very same skills necessary to evaluate competence in that domain" (Kruger and Dunning, 1999).

${ }^{24}$ We thank an anonymous referee for suggesting this explanation.

25 An earlier literature emphasized the acquisition of technological capabilities as the main determinant of industrial development (Amsden, 1989; Katz, 1984).
}

adoption of production export business practices would appear to be ultimately determined by the possession of foreign market knowledge. This hypothesis is consistent with evidence by Molina and Muendler (2013) and Mion and Opromolla (2010) who show that firms are more likely to export if they hire workers and managers with previous work experience at exporting firms. It is also consistent with casestudy evidence showing that the possession of foreign market knowledge is exhibited by many of the largest domestic manufacturers in Ethiopia (Sutton and Kellow, 2010) and Ghana (Sutton and Kpentey, 2012), and by African exporters (Easterly and Reshef, 2010).

\subsection{Diffusion of export business practices and emergence of new exporting sectors}

The adoption of export business practices is not confined to export pioneers. It has widely spread throughout the industry in television and wines, the two sectors where export growth has been starker, and it has been adopted by a few firms in motorboats. ${ }^{26}$ Since followers in contrast to export pioneers - are generally not embedded in foreign business networks, their acquisition of foreign market knowledge must rely on alternate channels of knowledge transmission. Here, we develop the hypothesis that export pioneers spur a diffusion process that eventually renders foreign market knowledge common wisdom within the industry local business community. Although our findings are too thin to uncover the actual channels of diffusion, we highlight those that our findings suggest are the most relevant ones.

The adoption of export business practices by the export pioneer is visible to other industry actors. While they might not observe all the actions of pioneers, they realize that he is adopting a new set of business practices and is making consistent efforts to export. Sometimes, export pioneers are themselves open and vocal about what they are doing. Their success has a demonstration effect. They set an observable benchmark that convinces others that there is a profitable way of approaching foreign markets. We believe that this is the most important role of the pioneer in the diffusion process.

The actions of export pioneers also transmit knowledge about markets and products. For example, winemakers in Mendoza knew that Catena was targeting the U.S. market and working with Cabernet Sauvignon and Chardonnay grapes. The actions of pioneers transmit more specific information as well. For instance, competitors might learn from suppliers and former employees that the pioneer has hired an international consultant or has implemented a certain type of technological upgrade. Export pioneers also help followers by opening gates in foreign markets. In particular, they help mitigate country-of-origin bias by establishing a positive reputation for the country as a reliable producer in the industry.

We argue that the most important advantage of export pioneers relative to other domestic producers is their possession of knowledge that is general, and hence diffusible. This knowledge is essentially the understanding that consumption patterns and business practices are systematically different in developed countries and the acknowledgment that the way of doing business needs to be changed in order to address those differences. We view this type of knowledge as general in the sense that it can be widely used in the sector. We hypothesize that it is susceptible to diffusion because it is manifest in the actions of pioneers, which are visible as they adopt the set of export business practices.

In developed countries, this type of general diffusion would be unnecessary for producers of differentiated products as they do not need to bridge such a divide in consumption patterns and business practices in order to export to other developed countries. The different environments in which producers in developed and developing countries operate can explain why international business studies that have long emphasized

\footnotetext{
${ }^{26}$ No firm has yet adopted the whole set of export business practices in furniture; i.e. there is not even an export pioneer.
} 
foreign market knowledge as a key determinant of firm internationalization (Johanson and Vahlne, 1977, 1990; Madsen and Servais, 1997; Sharma and Bomstermo, 2003) neglect the role of diffusion for acquiring this type of knowledge. Diffusion is less likely to occur in their case studies because they focus on firms from developed countries whose knowledge advantage consists of specific intricacies of foreign markets such as commercial secrets, business contacts, and details of the competition environment. While export pioneers in our cases might also be familiar with such intricacies, their main advantage is the possession of a more diffusible type of knowledge.

In the wine and television industries, multinationals entered the sector at relatively early stages in the diffusion process and currently account for a substantial fraction of production and exports. Nevertheless, in none of our cases is a multinational the export pioneer or one of the earliest adopters. While multinationals possess foreign market knowledge, they may be initially unconvinced that the business practices required to serve developed markets can be implemented under existing local conditions. Thus, they only enter the industry once the pioneer and early followers, who combine foreign and domestic market knowledge, demonstrate how this can be done. ${ }^{27}$

In contrast to the concerns of Hausmann and Rodrik (2003) about the harmful effect of diffusion on the discovery activity, our findings suggest that diffusion benefits more than harms export pioneers. Pioneers benefit from followers as they help develop brand recognition for the country's industry and from various forms of cooperation such as sharing stands at trade fairs, organizing trade missions jointly, or cross-offering products abroad. Notwithstanding this difference between HR and our findings, the importance of diffusion in both studies suggests that industries should be relevant units of analysis in the study of export development.

\section{Conclusions and policy implications}

Based on four case studies of new exporting sectors in Argentina, this article investigates the underlying determinants of the ability of firms from developing countries to successfully export differentiated goods to the developed world. We find that the most significant challenge facing exporters of such goods lay not in resolving problems in production but rather in acquiring knowledge about existing differences and evolving trends in the types of products demanded by consumers in these countries and knowing how to work with their distributors. The foreign embeddedness of export pioneers prior to engaging in their export venture enables them to acquire this knowledge and adapt their business practices accordingly. Their ability to integrate such knowledge into their production processes and successfully export their goods to developed countries sets a visible benchmark that enables future followers to understand what business practices they would need to change.

While export growth from developing countries has been largely linked to the ability of firms to work in GVC dominated by large companies in the developed world (Gereffi, 1999; Humphrey and Schmitz, 2002), our article highlights an alternate way of exporting differentiated goods that does not involve participating in them. Indeed, our work indicates that multinationals may not be the first to initiate production in a particular industry even if they eventually come to account for a significant portion of exports. Consequently, since product and marketing practices are greater hurdles for domestic firms, public policy for export development that focuses solely on production would seem to be misguided.

\footnotetext{
27 Wagner and Zhaler (2013) find that export pioneers tend to be smaller than their followers. They explain this finding with a model in which larger firms have more choices to allocate their managerial capacity and prefer to wait until their uncertainty is resolved by the actions of smaller firms.
}

The export of differentiated products requiring continual changes in design would seem to offer middle-income developing countries like Argentina the ability to resist the downward pressure on wages associated with the insertion in GVC and the production of commodities. Hence, our findings suggest that public policy that seeks to promote high-wage jobs should include export development policies that promote the diffusion of export business practices. Policy makers could, for example, promote conferences through business associations and educational institutions designed to facilitate the transmission of explicit and tacit knowledge from emerging pioneers to potential followers. Overall exports from countries like Argentina may have been less spectacular than exports from countries in Asia, not because firms have not inserted themselves in GVC but rather because the majority of firms have not come to understand the means for consistently exporting differentiated products to the developed world.

\section{Appendix A. Methodology}

\section{A.1. Quantitative identification of new exporting sectors}

This appendix describes our procedure for identifying new exporting differentiated-good sectors from customs data. Although our original database reports Argentina's exports at the 6-digit level of the Harmonized System (HS), we aggregate at the 4-digit level and use this level of aggregation to conduct the statistical analysis of sectoral export growth. We think that 4-digit categories best group products that share similar technologies, labor-skill needs, distribution channels and marketing requirements, and thus can be thought of as economic sectors. There are 1328 4-digit HS categories.

We consider export growth between the average of the periods 1991-1994 and 2002-2005. The Argentine economy underwent a period of drastic trade liberalization that was mostly complete by 1991 . Therefore, the choice of base period attempts to minimize the identification of sectors with emerging export activity driven by sectoral reallocation in response to trade liberalization. Averaging over four years prevents exceptional peaks - sometimes driven by measurement error - from dominating the measure of export growth.

We impose the following quantitative filters on the database. First, we require exports in 2005 to be above the threshold value of US\$ 10 million to exclude categories that have insufficient economic significance. This amount represents $0.025 \%$ of total Argentine exports and $0.091 \%$ of industrial manufacturing exports in that year. This criterion leaves 267 out of 1328 4-digit categories in the database. Second, we rank the remaining 267 categories according to export growth between 1991-1994 and 2002-2005, and select only those in the top 40 percentiles. Applying this criterion narrows the list to 106 4-digit categories. Finally, among those 106 categories, we select only those that have shipped more than a third of their exports to OECD countries. The application of this last filter results in a list of 30 4-digit sectors. Applying Rauch's (1999) classification, 13 sectors can be classified as differentiated (listed in Table A.1) and 17 as non-differentiated (listed in Table A.2).

Since categories in the Harmonized System do not necessarily correspond to relevant economic sectors, the industries we choose for case study do not exactly match the 4-digit categories used in the statistical analysis. One of our sectors, wooden furniture, straddles HS category 9403 ("furniture NESOI and parts thereof") and HS category 9401 ("seats (except barber, dental, etc.), and parts"). Both categories are included in Table A.1. Another of our selected sectors, wines, coincides with HS category 2204 ("wine of fresh grapes; grape must NESOI"). Although this category is classified in Table A.2 as "non-differentiated", we consider this classification to be the result of an ambiguity created by aggregation. Whereas this category is dominated by fine wines - a differentiated product - in Argentina's exports, Rauch (1999) classifies wine as a reference-price category maybe based on the category's inclusion of grape must and table wine. A third of our sectors, motorboats, is very hard to identify using customs data since not even at the finest 
levels of disaggregation does the HS classification discriminate by tonnage or length. Once properly defined, the motorboat industry passes all the criteria established above, except for its value of shipments which is slightly below the minimum threshold of US\$10 million. Finally, information about exports in our fourth sector, television programs, is not included in customs data.

For a number of sectors listed in Tables A.1 and A.2, growth is primarily driven by the increasing exploitation of resource-based comparative advantage in response to trade liberalization and deregulation. For instance, this is the case of copper ores (HS 2603), leather (HS 4107) and wood boards (HS 4407, 4409 and 4421). A few other sectors are highly idiosyncratic. On the one hand, nuclear reactors (HS 8401) are exported by only one government-owned agency. On the other hand, exports reported under "reaction initiators and accelerators and catalyst preparations NESOI" (HS 3815), "turbojets, turbo propellers and other gas turbines and parts" (HS 8411) and "aircraft" (HS 8802) correspond to sales of used equipment, previously imported. Netting these sectors out from the list and re-classifying wine as a differentiated product places wines, seats and seat parts, and furniture at the top of an export-ranked list of differentiated products with high export growth and substantial orientation toward OECD markets.

\section{Appendix B. Argentina's exports of differentiated goods to the OECD}

After a decade of commercial protection and high inflation, in the early 1990s the Argentine government instituted a drastic reform and stabilization program that included unilateral trade liberalization, opening of the capital account, removal of restrictions on FDI, privatization, de-regulation, and a currency board that pegged the peso to the U.S. dollar. Most of the decade witnessed high rates of economic growth and a strong real appreciation of the domestic currency (Fig. A.1). The program culminated in a severe financial, currency, and debt crisis that took place in 2001 and 2002. The recovery from the crisis, however, was rapid, and the rest of the 2000s until 2008 exhibited high rates of economic growth associated with a depreciated domestic currency at approximately half of the value of the multilateral real exchange rate that prevailed in the 1990s.

Total exports picked up in the early 1990s as a result of the liberalization program. They grew steadily over most of that decade but eventually stalled due to the loss of international competitiveness brought about by the real appreciation of the peso, particularly after Brazil devalued its currency in 1999. International competitiveness was regained following the crisis and the large devaluation that ensued in January 2002 (see Fig. A.2). Exports grew vigorously for the rest of the

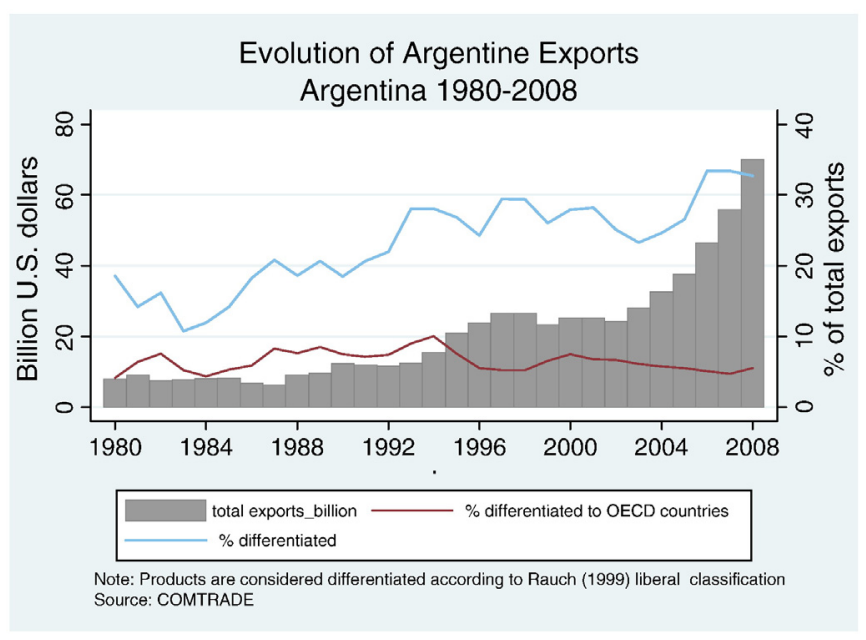

Fig. A.2. Evolution of argentine exports: Argentina 1980-2008.

decade. Fig. A.2 also shows that the share of differentiated products in total exports from Argentina increased from 18\% of total exports in 1980 to $32.7 \%$ in 2008 . However, exports to the developing world, particularly neighboring MERCOSUR countries, explain most of this growth. As a result, exports of differentiated products to OECD countries have consistently accounted for less than $10 \%$ of Argentina's total exports.

For comparison, Fig. A.3 shows the evolution of this same share between 1980 and 2006 across regions in the world. In most regions of the developing world, the share of differentiated goods exported to OECD countries has increased considerably, albeit largely based on exports of apparel (SITC 84). This is true for Central America, North Africa, Eastern Europe, the Middle East, and particularly South Asia. By contrast, South America, Sub-Saharan Africa, and Oil abundant economies all exhibit stagnant shares of differentiated-good exports to the OECD under $10 \%$ of total exports. The weak performance of South America is particularly interesting in the context of our study as it shows that Argentina's apparent lack of international competitiveness in this type of exports is not exceptional in the region.

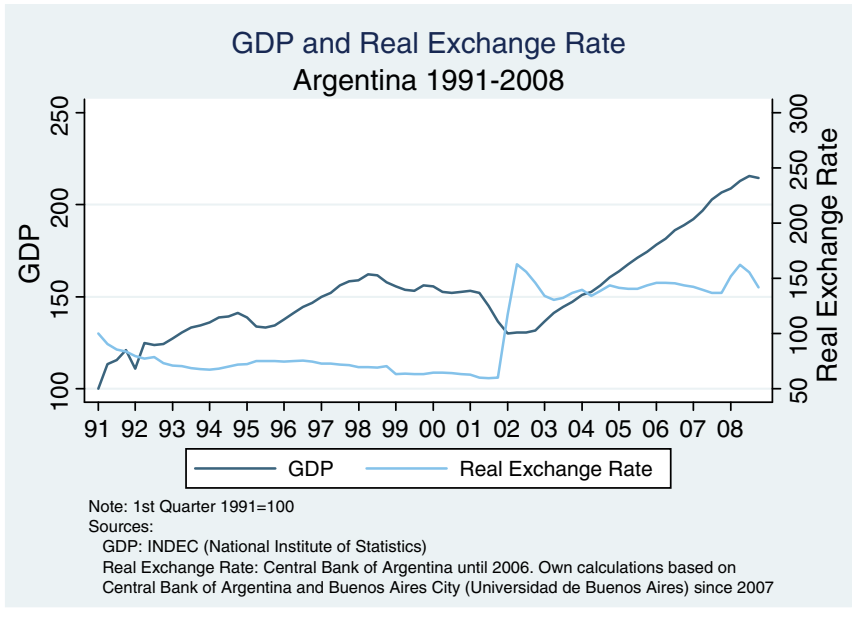

Fig. A.1. GDP and real exchange rate: Argentina 1991-2008.

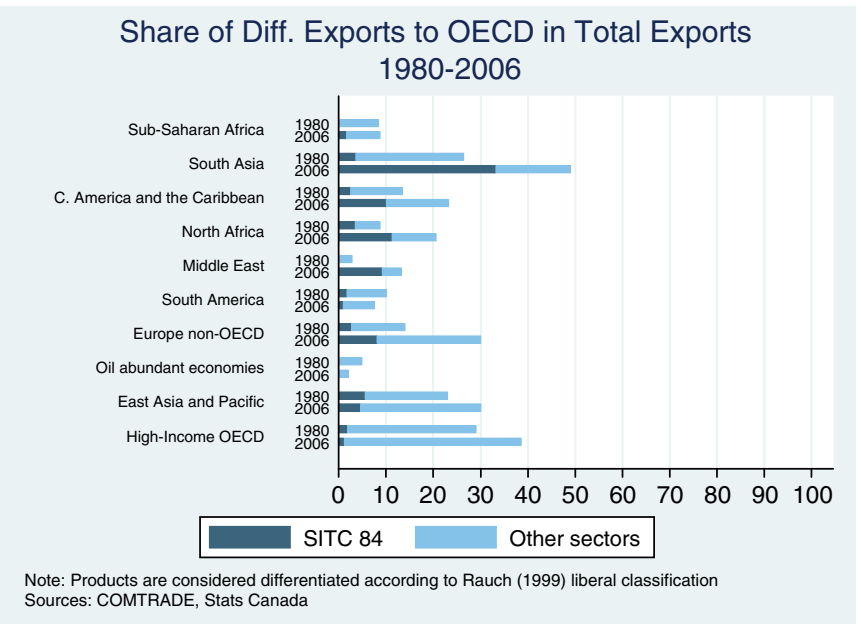

Fig. A.3. Share of diff. exports to OECD in total exports: 1980-2006. 
Table A.1

High growth, high value sectors with large exports to OECD. Differentiated.

\begin{tabular}{|c|c|c|c|c|}
\hline \multirow[t]{3}{*}{ HS4 } & \multirow{2}{*}{$\frac{\text { Exports }}{2005}$} & \multirow{2}{*}{$\frac{\text { To }}{\mathrm{OECD}}$} & \multirow[t]{3}{*}{ Growth $^{\mathrm{a}}$} & \multirow[t]{3}{*}{ Description } \\
\hline & & & & \\
\hline & $(\mathrm{US} \$ \mathrm{M})$ & $(\%)$ & & \\
\hline 3815 & 41 & 36 & 13.1 & Reaction initiators \& acceler \& catalyt prep NESOI \\
\hline 9403 & 36.3 & 36 & 5 & Furniture NESOI and parts thereof \\
\hline 4409 & 30.4 & 93 & 49.3 & Wood, continuously shaped (tongued, grooved etc.) \\
\hline 6907 & 27.2 & 94 & 32.4 & Unglazed ceramic flags \& paving, hearth tiles etc. \\
\hline 8401 & 17.6 & 100 & 6.6 & Nuclear reactors; fuel elem $(n-i)$; mach isotop sep \\
\hline 8455 & 17.5 & 51 & 5.7 & Metal-rolling mills and rolls therefor; parts \\
\hline 8516 & 12.5 & 35 & 4.6 & Elec water, space \& soil heaters; hair etc. dry, pt \\
\hline 4421 & 12 & 89 & 16.7 & Articles of wood, NESOI \\
\hline 8411 & 11.9 & 50 & 11.8 & Turbojets, turbopropellers \& oth gas turbines, pts \\
\hline \multirow[t]{2}{*}{6109} & 10.4 & 47 & 14.7 & t-Shirts, singlets, tank tops etc., knit or crochet \\
\hline & 39,876 & 69 & 2.4 & Total exports \\
\hline
\end{tabular}

a Growth: ratio between the average for 2002-2005 and the average for 1991-1994.

Table A.2

High growth, high value sectors with large exports to OECD. Non-differentiated.

\begin{tabular}{|c|c|c|c|c|}
\hline \multirow[t]{3}{*}{ HS4 } & \multirow{2}{*}{$\frac{\text { Exports }}{2005}$} & \multirow{2}{*}{$\frac{\text { To }}{\text { OECD }}$} & \multirow[t]{3}{*}{ Growth $^{\mathrm{a}}$} & \multirow[t]{3}{*}{ Description } \\
\hline & & & & \\
\hline & $\overline{(\mathrm{US} \$ \mathrm{M})}$ & $(\%)$ & & \\
\hline 2603 & 1026.9 & 42 & 318,783 & Copper ores and concentrates \\
\hline 2204 & 303.7 & 67 & 6.8 & Wine of fresh grapes; grape must NESOI \\
\hline 4107 & 268.1 & 41 & 57.8 & Leather of animals NESOI, no hair NESOI \\
\hline 7210 & 166.6 & 51 & 6.3 & fl-rl iron \& na steel nun $600 \mathrm{~mm}$ wd, clad etc. \\
\hline 7108 & 145.4 & 70 & 16.2 & Gold (incl plat plated), unwr, semimfr or powder \\
\hline 2008 & 130.5 & 70 & 5.4 & Fruit, nuts etc. prepared or preserved NESOI \\
\hline 2905 & 110 & 65 & 5.3 & Acyclic alcohols \& halogenat, sulfonatd etc. derivs \\
\hline 806 & 75.7 & 60 & 5.2 & Grapes, fresh or dried \\
\hline 7224 & 54 & 99 & 1144.5 & Alloy steel NESOI in ingots, oth pr frm \& semif pr \\
\hline 2302 & 52.1 & 91 & 5.1 & Bran, sharps etc. from working cereals \& leg plants \\
\hline 7214 & 39.6 & 64 & 8.5 & Bars \& rods, iron \& na steel NESOI, h-r etc. \\
\hline 2827 & 38 & 70 & 149.2 & Chlorides etc.; bromides etc.; iodides etc. \\
\hline 2901 & 30.1 & 60 & 27.1 & Acyclic hydrocarbons \\
\hline 810 & 28.9 & 99 & 126.8 & Fruit NESOI, fresh \\
\hline 3913 & 24.9 & 34 & 166.4 & Natural (inc modified) polymers NESOI, primary forms \\
\hline 2836 & 19.4 & 62 & 21.6 & Carbonates; peroxocarbonates; comm amm carbonate \\
\hline \multirow[t]{2}{*}{811} & 11.1 & 72 & 434.6 & Fruit \& nuts (raw or cooked by steam etc.), frozen \\
\hline & 39,876 & 69 & 2.4 & Total exports \\
\hline
\end{tabular}

a Growth: ratio between the average for 2002-2005 and the average for 1991-1994.

Table A.3

List of interviews.

\begin{tabular}{|c|c|c|c|c|c|}
\hline Case & Organization & Type of organization & Position & Date & Location \\
\hline Motorboats & Altamar & Company & Production Director & Jul 05, 2006 & $\begin{array}{l}\text { San Fernando, Buenos Aires, } \\
\text { Argentina }\end{array}$ \\
\hline Motorboats & Altamar & Company & Commercial Director & Jul 05, 2006 & $\begin{array}{l}\text { San Fernando, Buenos Aires, } \\
\text { Argentina }\end{array}$ \\
\hline Motorboats & CACEL & Chamber & Director & Mar 27, 2006 & $\begin{array}{l}\text { San Fernando, Buenos Aires, } \\
\text { Argentina }\end{array}$ \\
\hline Motorboats & CEE & Company & Owner/CEO & Jun 28, 2006 & $\begin{array}{l}\text { San Fernando, Buenos Aires, } \\
\text { Argentina }\end{array}$ \\
\hline Motorboats & CEE & Company & Owner/CEO & Dec 19, 2010 & $\begin{array}{l}\text { San Fernando, Buenos Aires, } \\
\text { Argentina }\end{array}$ \\
\hline Motorboats & CEE & Company & Owner/CEO & Jul 20, 2012 & $\begin{array}{l}\text { San Fernando, Buenos Aires, } \\
\text { Argentina }\end{array}$ \\
\hline Motorboats & GG Yacht Designer & Yacht Designer & Owner/CEO & Jul 07, 2006 & $\begin{array}{l}\text { Olivos, Buenos Aires, } \\
\text { Argentina }\end{array}$ \\
\hline Motorboats & Segue & Company & Owner/CEO & Aug 10, 2006 & $\begin{array}{l}\text { San Fernando, Buenos Aires, } \\
\text { Argentina }\end{array}$ \\
\hline TV programs & Fox & Broadcaster & Manager & Jun 27, 2006 & Milan, Italy (by phone) \\
\hline TV programs & Promofilm & Company & Owner/CEO & Jun 20, 2006 & $\begin{array}{l}\text { City of Buenos Aires, } \\
\text { Argentina }\end{array}$ \\
\hline
\end{tabular}


Table A.3 (continued)

\begin{tabular}{|c|c|c|c|c|c|}
\hline Case & Organization & Type of organization & Position & Date & Location \\
\hline TV programs & Promofilm & Company & Owner/CEO & Jul 06, 2012 & $\begin{array}{l}\text { City of Buenos Aires, } \\
\text { Argentina }\end{array}$ \\
\hline TV programs & Promofilm & Company & $\begin{array}{l}\text { Senior Vice President } \\
\text { Development and Production }\end{array}$ & Jun 13, 2006 & $\begin{array}{l}\text { City of Buenos Aires, } \\
\text { Argentina }\end{array}$ \\
\hline TV programs & Tandem & Company & Owner/CEO & Oct 10, 2006 & $\begin{array}{l}\text { City of Buenos Aires, } \\
\text { Argentina }\end{array}$ \\
\hline TV programs & TELEFE & Consultant & Consultant & Jun 22, 2006 & $\begin{array}{l}\text { City of Buenos Aires, } \\
\text { Argentina }\end{array}$ \\
\hline TV programs & TELEFE International & Company & International Manager & Oct 24,2006 & $\begin{array}{l}\text { City of Buenos Aires, } \\
\text { Argentina }\end{array}$ \\
\hline Wines & $\begin{array}{l}\text { Asociación Argentina de Consorcios } \\
\text { Regionales de Experimentación Agraria } \\
\text { (AACREA) }\end{array}$ & $\begin{array}{l}\text { NGO of agricultural research } \\
\text { and improvement }\end{array}$ & Regional Coordinator & Jul 14, 2006 & Mendoza, Argentina \\
\hline Wines & Catena Zapata & Company & Winemaker & Sep 27, 2006 & Mendoza, Argentina \\
\hline Wines & Catena Zapata & Company & Owner/CEO & Nov 16, 2006 & $\begin{array}{l}\text { City of Buenos Aires, } \\
\text { Argentina }\end{array}$ \\
\hline Wines & Chandon & Company & Export Manager & Sep 25, 2006 & $\begin{array}{l}\text { City of Buenos Aires, } \\
\text { Argentina }\end{array}$ \\
\hline Wines & $\begin{array}{l}\text { COVIAR (Corporación Vitivinícola } \\
\text { Argentina) }\end{array}$ & Wine Umbrella Association & Director & Jul 20, 2006 & $\begin{array}{l}\text { City of Buenos Aires, } \\
\text { Argentina }\end{array}$ \\
\hline Wines & Diageo & Company & Export Manager & Oct 30,2006 & $\begin{array}{l}\text { City of Buenos Aires, } \\
\text { Argentina }\end{array}$ \\
\hline Wines & $\begin{array}{l}\text { Fecovita (Federación de Cooperativas } \\
\text { Vitivinícolas Argentinas) }\end{array}$ & Cooperative & Export Manager & Sep 28, 2006 & Mendoza, Argentina \\
\hline Wines & Flichman & Company & Vice President/CEO & Aug 29, 2006 & $\begin{array}{l}\text { City of Buenos Aires, } \\
\text { Argentina }\end{array}$ \\
\hline Wines & Grupos CREA & $\begin{array}{l}\text { Farm improvement } \\
\text { association }\end{array}$ & Manager & Jul 14, 2006 & $\begin{array}{l}\text { City of Buenos Aires, } \\
\text { Argentina }\end{array}$ \\
\hline Wines & $\begin{array}{l}\text { INTA (Instituto Nacional de Tecnología } \\
\text { Agropecuaria) }\end{array}$ & $\begin{array}{l}\text { Federal agricultural research } \\
\text { agency }\end{array}$ & Director & Sep 28, 2006 & Mendoza, Argentina \\
\hline Wines & $\begin{array}{l}\text { INTA (Instituto Nacional de Tecnología } \\
\text { Agropecuaria) }\end{array}$ & $\begin{array}{l}\text { Federal agricultural research } \\
\text { agency }\end{array}$ & Manager & Sep 28, 2006 & Mendoza, Argentina \\
\hline Wines & La Agrícola S.A. & Company & Director/Owner & Sep 30, 2006 & Mendoza, Argentina \\
\hline Wines & Peñaflor & Company & Export Director & Aug 30, 2006 & $\begin{array}{l}\text { City of Buenos Aires, } \\
\text { Argentina }\end{array}$ \\
\hline Wines & Schroeder Family & Company & Export Manager & Jul 14, 2006 & $\begin{array}{l}\text { City of Buenos Aires, } \\
\text { Argentina }\end{array}$ \\
\hline Wines & Trivento & Company & Export Manager & Sep 25, 2006 & Mendoza, Argentina \\
\hline Wines & Wines of Argentina & Wine Export Association & Manager & Sep 11, 2006 & $\begin{array}{l}\text { City of Buenos Aires, } \\
\text { Argentina }\end{array}$ \\
\hline Wines & Wines of Argentina & Wine Export Association & Director & Jul 12, 2006 & $\begin{array}{l}\text { City of Buenos Aires, } \\
\text { Argentina }\end{array}$ \\
\hline Wooden furniture & CAFYDMA & Association & Director & Mar 10, 2006 & $\begin{array}{l}\text { City of Buenos Aires, } \\
\text { Argentina }\end{array}$ \\
\hline Wooden furniture & $\begin{array}{l}\text { FAIMA (Federación Argentina de la } \\
\text { Industria de la Madera y Afines) }\end{array}$ & Chamber & Director & Jul 13, 2006 & $\begin{array}{l}\text { City of Buenos Aires, } \\
\text { Argentina }\end{array}$ \\
\hline Wooden furniture & Ivope & Company & Export Manager & Nov 10, 2006 & $\begin{array}{l}\text { San Jerónimo Norte, Santa } \\
\text { Fe, Argentina }\end{array}$ \\
\hline Wooden furniture & Jorge Etchebehere Trading Co & Broker & Owner & Dec 09, 2006 & $\begin{array}{l}\text { City of Buenos Aires, } \\
\text { Argentina }\end{array}$ \\
\hline Wooden furniture & Jorge Etchebehere Trading Co & Broker & Owner & Sep 12, 2006 & $\begin{array}{l}\text { City of Buenos Aires, } \\
\text { Argentina }\end{array}$ \\
\hline Wooden furniture & Mehring & Designer & Designer & Nov 12, 2006 & $\begin{array}{l}\text { Esperanza, Santa Fe, } \\
\text { Argentina }\end{array}$ \\
\hline Wooden furniture & Mehring & Company & Owner/CEO & Jul 27, 2006 & Buenos Aires, Argentina \\
\hline Wooden furniture & Reno & Company & Owner/CEO & Nov 10, 2006 & Alvarez, Santa Fe, Argentina \\
\hline
\end{tabular}

\section{References}

Abernathy, F., Dunlop, J., Hammond, J., Weil, D., 1999. A Stitch in Time: Lean Retailing and the Transformation of Manufacturing-Lessons from the Apparel and Textile Industries. Oxford University Press, London.

Amsden, A., 1989. Asia's Next Giant: South Korea and Late Industrialization. Oxford University Press, London.

Antràs, P., Costinot, A., 2011. Intermediated trade. Quarterly Journal of Economics 126 (3), 1319-1374.

Antràs, P., Foley, C., 2011. Poultry in motion: a study of international trade finance practices. NBER Working Paper No. 17091.

Arbeláez, M., Meléndez, M., León, N., 2012. The emergence of fresh cut-flower exports in Colombia. In: Sabel, Ch., Fernández-Arias, E., Hausmann, R., Rodríguez-Clare, A., Stein, E. (Eds.), Export Pioneers in Latin America. IDB-DRCLAS. Harvard University, Cambridge, MA, pp. 69-100.

Arkolakis, C., 2010. Market penetration costs and the new consumers margin in international trade. Journal of Political Economy 118 (6), 1151-1199.

Artopoulos, A., Friel, D., Hallak, J., 2011a. Lifting the domestic veil: the challenges of exporting differentiated goods across the development divide. NBER Working Paper 16947.
Artopoulos, A., Friel, D., Hallak, J., 2011b. Export Emergence of Differentiated Goods from Developing Countries: Four Argentine Cases, Economics Department WP No. 107 Universidad de San Andrés.

Bernard, A., Eaton, J., Jensen, B., Kortum, S., 2003. Plants and productivity in international trade. The American Economic Review 93 (4), 1268-1290.

Bilkey, W., Nes, E., 1982. Country-of-origin effects on product evaluation. Journal of International Business Studies 13, 89-99.

Bloom, N., Van Reenen, J., 2010. Why do management practices differ across firms and countries? The Journal of Economic Perspectives 24 (1), 203-224.

Blum, B., Claro, S., Horstmann, I., 2013. Occasional and perennial exporters. Journal of International Economics 90 (1), 65-74.

Brambilla, I., Lederman, D., Porto, G., 2012. Exports, export destinations and skills. American Economic Review 102 (7), 3406-3438.

Burt, R., 1992. Structural Holes. Harvard University Press, Cambridge, MA.

Easterly, W., Reshef, A., 2010. African export successes: surprises, stylized facts, and explanations. NBER Working Paper 16597.

Egan, M., Mody, A., 1992. Buyer-seller links in export development. World Development 20 (3), 321-334

Eisenhardt, K., 1989. Building theories from case studies research. Academy of Management Review 14 (4), 532-550. 
Eisenhardt, K., Graebner, M., 2007. Theory building from cases: opportunities and challenges. The Academy of Management Journal Archive 50 (1), 25-32.

FRAPA (Format Recognition and Protection Association), 2009. FRAPA report: TV formats to the world. Available at http://www.frapa.org/press.html (Accessed September 7, 2009).

Freund, C., Pierola, M., 2010. Export entrepreneurs: evidence from Peru. The World Bank Policy Research Working Paper 5407.

Friel, D., 2011. Forging a comparative institutional advantage in Argentina: implications for theory and praxis. Human Relations 64 (4), 553-572.

Gereffi, G., 1999. International trade and industrial upgrading in the apparel commodity chain. Journal of International Economics 48 (1), 37-70.

Glaser, B., Strauss, A., 1967. Discovery of Grounded Theory. Strategies for Qualitative Research. Aldine Publishing Company, Chicago.

Granovetter, M., 1973. The strength of weak ties. The American Journal of Sociology 78 (6), $1360-1380$.

Granovetter, M., 1985. Economic action and social structure: the problem of embeddedness. The American Journal of Sociology 91 (3), 481-510.

Granovetter, M., 2005. The impact of social structure on economic outcomes. Journal of Economic Perspectives 19 (1), 33-50.

Hallak, J., Sivadasan, J., 2013. Product and process productivity: implications for quality choice and conditional exporter premia. Journal of International Economics (forthcoming, http://www.sciencedirect.com/science/journal/aip/00221996).

Hausmann, R., Rodrik, D., 2003. Economic development as self-discovery. Journal of Development Economics 72 (2), 603-633.

Helper, S., 2000. Economists and field research: "you can observe a lot just by watching". American Economic Review 90 (2), 228-232.

Humphrey, J., Schmitz, H., 2002. How does insertion in global value chains affect upgrading in industrial clusters? Regional Studies 36 (9), 1017-1027.

Iacovone, L., Javorcik, B., 2010. Multi-product exporters: product churning, uncertainty and export discoveries. The Economic Journal 120, 481-499.

Ichniowski, C., Shaw, K., 2003. Beyond incentive pay: insiders' estimates of the value of complementary human resource management practices. The Journal of Economic Perspectives 17 (1), 155-180.

Johanson, J., Vahlne, J., 1977. The internationalization process of the firm: a model of knowledge development and increasing foreign market commitments. Journal of International Business Studies 8 (1), 23-32.

Johanson, J., Vahlne, J., 1990. The mechanism of internationalization. International Marketing Review 7 (4), 11-24.

Katz, J., 1984. Domestic technological innovations and dynamic comparative advantage. Journal of Development Economics 16 (1-2), 13-37.

Keesing, D., Lall, S., 1990. Marketing manufactured exports from developing countries: learning sequences and public support. In: Helleiner, G. (Ed.), Trade Policy, Industrialization, and Development: New Perspectives. Clarendon Press, Oxford.

Klepper, S., Romel, M., 2011. Industrial development through tacit knowledge seeding evidence from the Bangladesh garment industry. Mimeo.

Kogut, B., Singh, H., 1988. The Effect of National Culture on the Choice of Entry Mode. Journal of International Business Studies 19 (3), 411-432.

Kruger, J., Dunning, D., 1999. Unskilled and unaware of it: how difficulties in recognizing one's own incompetence lead to inflated self-assessments. Journal of Personality and Social Psychology 77 (6), 1121-1134.

Kugler, M., Verhoogen, E., 2012. Prices, plant size, and product quality. The Review of Economic Studies 79 (1), 307-339.
Macchiavello, R., 2011. Financial development and vertical integration: theory and evidence. Journal of the European Economic Association 10 (2), 255-289.

Madsen, T., Servais, P., 1997. The internationalization of born globals: an evolutionary process? International Business Review 6 (6), 561-583.

Manova, K., Zhang, Z., 2012. Export prices across firms and destinations. Quarterly Journal of Economics 127 (1), 379-436.

McDermott, G., 2007. The politics of institutional renovation and economic upgrading: recombining the vines that bind in Argentina. Politics \& Society 35 (1), 103-143.

Melitz, M., 2003. The impact of trade on intra-industry reallocations and aggregate industry productivity. Econometrica 71 (6), 1695-1725.

Melitz, M., Redding, S., 2013. Heterogeneous firms and trade, Handbook of International Economics, 4th ed. (forthcoming, http://www.princeton.edu/ reddings/redpublish. htm).

Mion, G., Opromolla, L., 2010. Managers' mobility, trade status, and wages. CEPR Discussion Paper No. 8230. Centre for Economic Policy, London.

Molina, D., Muendler, M., 2013. Preparing to export. NBER Working Paper 18962

Nonaka, I., 1994. A dynamic theory of organizational knowledge creation. Organization Science 5 (1), 14-37.

Powell, W., 1990. Neither market nor hierarchy: network forms of organization. Research in Organizational Behavior 12, 295-336.

Rauch, J., 1999. Networks versus markets in international trade. Journal of International Economics 48 (1), 7-35.

Rauch, J., Watson, J., 2004. Network intermediaries in international trade. Journal of Economics and Management Strategy 13 (1), 69-93.

Rhee, Y., 1990. The catalyst model of development: lessons from Bangladesh's success with garment exports. World Development 18 (2), 333-346.

Rhee, Y., Belot, T., 1990. Export catalysts in low-income countries: a review of eleven success stories. World Bank Discussion Paper, 72. World Bank, Washington, DC.

Roberts, M., Tybout, J., 1997. The decision to export in Colombia: an empirical model of entry with sunk costs. American Economic Review 87 (4), 545-563.

Sabel, C., Fernández-Arias, E., Hausmann, R., Rodríguez-Clare, A., Stein, E. (Eds.), 2012. Export pioneers in Latin America, IDB-DRCLAS. Harvard University, Cambridge, MA.

Schmitz, H., 1995. Collective efficiency: growth path for small-scale industry. Journal of Development Studies 31 (4), 529-566.

Sharma, D., Bomstermo, A., 2003. The internationalization process of born globals: a network view. International Business Review 12 (6), 739-753.

Shenkar, O., 2001. Cultural distance revisited. Journal of International Business Studies 32, 519-535.

Sutton, J., 2007. Quality, trade and the moving window: the globalisation process. The Economic Journal 117 (524), 469-498.

Sutton, J., Kellow, N., 2010. An Enterprise Map of Ethiopia. International Growth centre, London.

Sutton, J., Kpentey, B., 2012. An Enterprise Map of Ghana. International Growth Centre, London.

Uzzi, B., 1997. Social structure and competition in interfirm networks: the paradox of embeddedness. Administrative Science Quarterly 42 (1), 35-67.

Verhoogen, E., 2008. Trade, quality upgrading, and wage inequality in the Mexican manufacturing sector. Quarterly Journal of Economics 123 (2), 489-530.

Verleigh, P., Steenkamp, J., 1999. A review and meta-analysis of country-of-origin research. Journal of Economic Psychology 20, 521-546.

Wagner, R. and Zhaler, A., 2013. New exports from emerging markets: do followers benefit from pioneers? Mimeo.

Yin, R., 1994. Case Study Research: Design and Methods, second ed. Sage, Newbury Park, CA. 